\title{
STŘEDOVĚKÁ ÚPRAVNA RUD U KOJEČÍNA NA ČESKOMORAVSKÉ VRCHOVINĚ: K POZNÁNÍ TECHNOLOGIÍ PRODUKCE STŘÍBRA VE STÁTĚ POSLEDNÍCH PŘEMYSLOVCŮ
}

\author{
PETR HRUBÝ - MARTIN KOŠŤÁL - KAREL MALÝ - JAKUB TĚSNOHLÍDEK
}

\begin{abstract}
Abstrakt: Přispěvek představuje výzkum zpracovatelského areálu ze 13. století zapojeného do produkce střibra. Sondáž se zaměrila na soustavu úpravnických hald v trvale zvodněném prostředí. Zkoumána a analyzována byla natěžená a upravovaná rudnina. Dokumentovány byly technogenní uloženiny se znaky mletí a praní. Na bázi tělesa byla dochována dřeva smýcená po polovině 13. století. Mezi nimi lze rozlišit nejprve pokácený lesni porost a následně i konstrukčni dřeva. Zkoumanou strukturu interpretujeme jako pozůstatky středověké úpravny polymetalických rud, jejiž úlohou byla produkce rudního koncentrátu. Z technologického řetězce je zde doloženo tř́děni rud, stoupování, mletí a gravitační separace.
\end{abstract}

Klićová slova: střibrorudné hornictví-13. století- Českomoravská vrchovina.

A medieval ore mill near Koječín, in the Bohemian-Moravian Highlands: A contribution to the study of silver production technologies in the state of the last Přmyslids

\begin{abstract}
This contribution presents research into a 13th-century ore-processing complex involved in the production of silver. Test digs centred on a system of slag heaps in a permanently water-filled environment. The mined and cleaned ore was investigated and analysed, and technogennous deposits with traces of grinding and washing were documented. Wood cut after the mid-13th century was preserved in the form of objects. The wood can be divided into felled forest growth and timber subsequently used for construction. The investigated structure can be interpreted as the remains of a medieval polymetallic ores mill producing ore concentrate. Of the technology chain, the sizing of ores, the crushing, grinding and gravitation separation processes were recorded.
\end{abstract}

Key words: silver mining - 13th century - Bohemian-Moravian Highlands.

\section{1 Úvod}

Na základě sondáží v důlním a úpravnickém areálu u Koječína na Havlíčkobrodsku přináší studie nové poznatky o středověké důlní činnosti zaměřené na exploataci stříbronosných rud. Přemyslovské země zažívaly od poloviny 13. století především zásluhou středisek na Českomoravské vrchovině rozkvět produkce barevných kovů, zejména olova, stříbra a také mědi. Do tohoto období patř́i i zkoumaný úpravnický areál (obr. 1:7). Ten navazuje na rozsáhlá důlní pracoviště (obr. 2 a 3 ).

Datování do období rozkvětu těžby stříbronosných rud za posledních Přemyslovců dokládá série dendrochronologických dat z rozmezí let 1252/1253 a 1257/1258 (tab. 1) ze smýcených dřev v profilu 1 a 3 (Kyncl 2018). Počátek předpokládané těžby rud u Koječína po polovině 13. století zapadá i do územního, stejně jako časového rámce listinných pramenů. V roce 1252 je zmíněn mincmistr Jindřich v Humpolci (CDB IV/1, 436-437 č. 256), vzdáleném $8 \mathrm{~km}$. V severovýchodním sousedství, u Havlíčkova Brodu, se pak v listině Smila z Lichtenburka roku 1257 uvádí stř́ibrné doly u Brodu, Bělé, Přibyslavi a Šlapanova (CDB V/1, 223 č. 138; srov. Rous 2004).

Lokalita je odborně evidována řadu let a $\mathrm{v}$ minulosti zde byl během průzkumu $\mathrm{P}$. Rouse získán i soubor středověké keramiky (Rous-Malý 2004, 123 a 131, obr. 1:12). Z hlediska plochy určené k exkavaci a již prozkoumaného terénu lze práce považovat z $90 \%$ za dokončené. Úplné ukončení se předpokládá $\mathrm{v}$ roce 2019.

Mezi motivy současné exkavace převládala potřeba záchrany. Na jaře 2016 zjistil pracovník Muzea Vysočiny Jihlava (MVJ) J. Havlíček, že eroze jedné z hald rudniny odkryla v jejím tělese opracované dřevo. Kromě toho bylo shledáno, že těleso se hroutí i pod kořenovým systémem menších smrků na nesoudržném okraji. Tato fakta spolu se zjištěním nekontrolované detektorové činnosti vedla k rozhodnutí provést na ohroženém místě sondážní výzkum. 


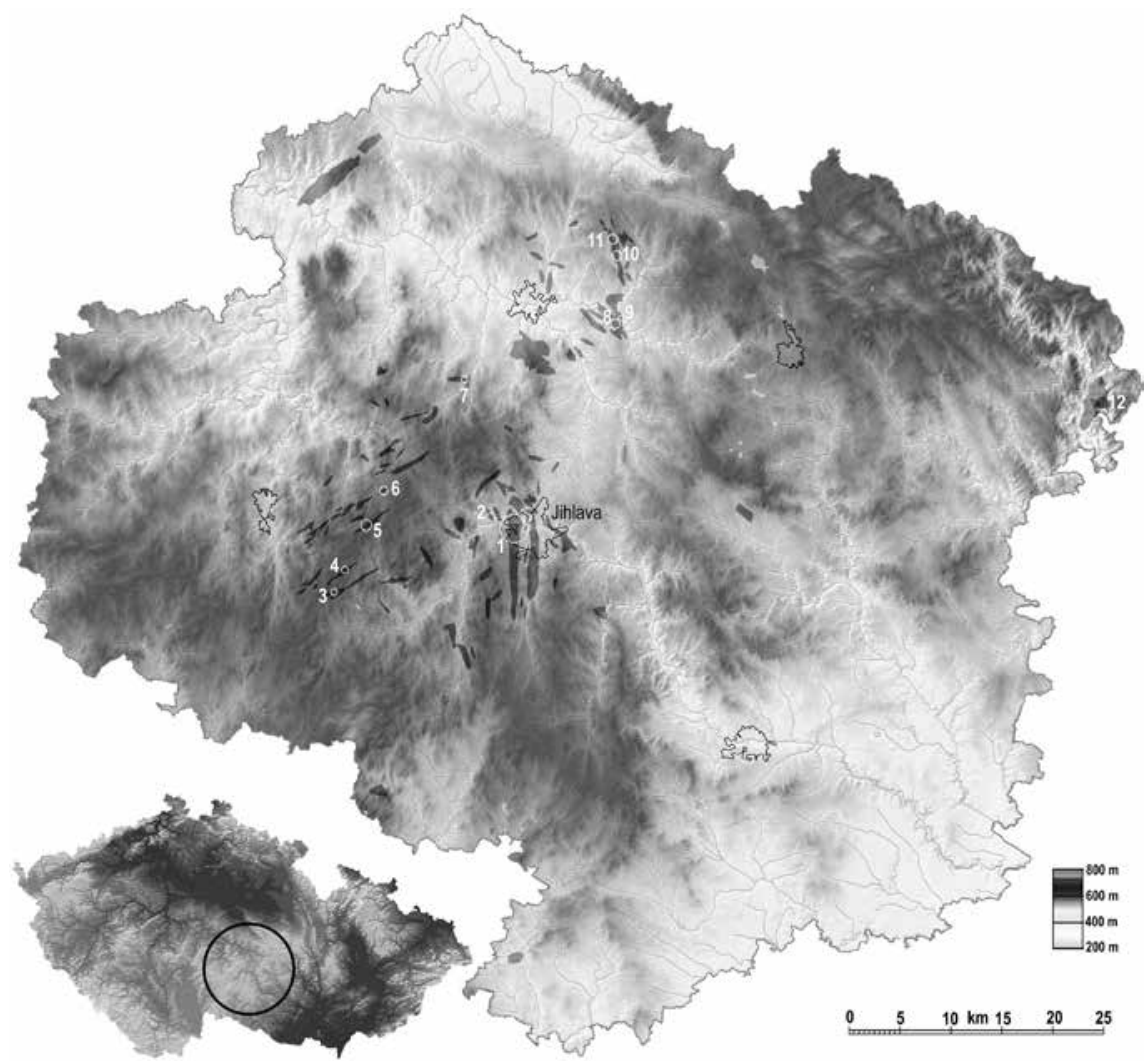

Obr. 1. Kraj Vysočina. Šedě stínovány širší oblasti polymetalické mineralizace. 1-6, 8-11 - Zkoumané montánní areály 13. století; 7 - Koječín.

Abb. 1. Landkreis Vysočina. Grau schattiert breitere Gebiete einer Polymetallmineralisierung 1-6, 8-11 - Untersuchte Montanareale des 13. Jahrhunderts; 7 - Koječín.

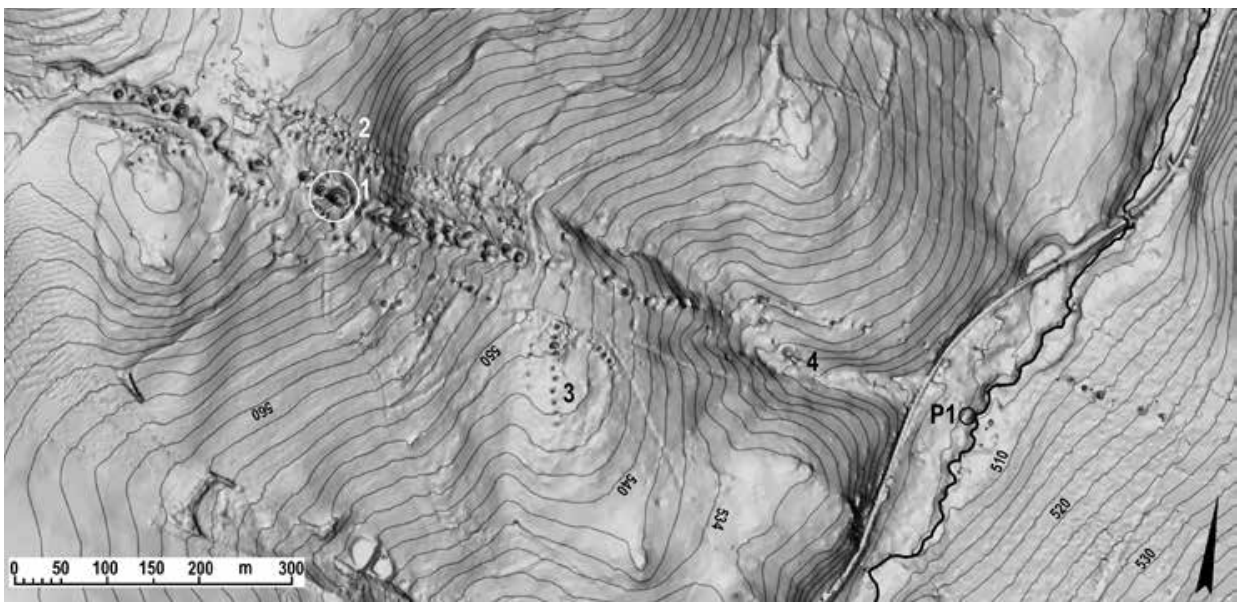

Obr. 2. Dủlní a zpracovatelský areál u Koječína na reliéfní mapě LiDAR 5G (ALS). 1 - důlní jámy (viz obr. 4); 2, 3 - systémy kutacích šachet; 4 - montánní relikty v bočním údolí; P1 - profil 1. Zpracoval a upravil M. Košt’ál.

Abb. 2. Gruben- und Verarbeitungsareal bei Koječín auf einer LiDAR 5G (ALS) basierenden Reliefkarte. 1 - Abbaugruben (siehe Abb. 4); 2, 3 - Schürfschächtesysteme; 4 - montane Relikte in einem Seitental; P1 - Profil 1. Erstellt und bearbeitet von M. Košt’ál. 


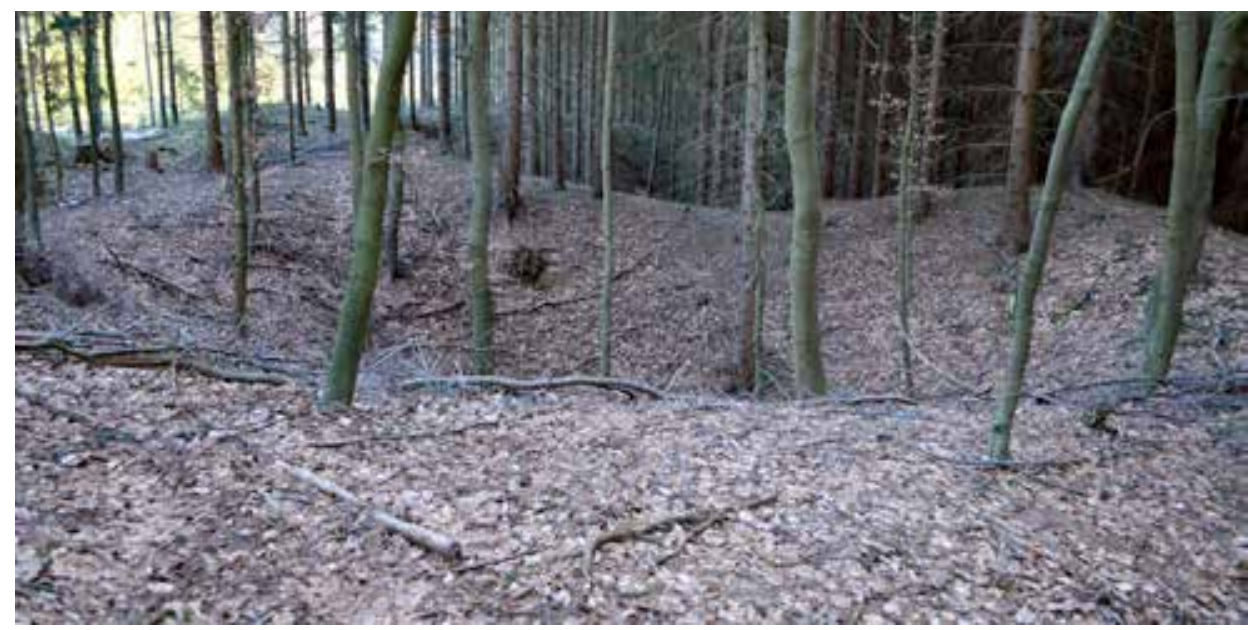

Obr. 3. Těžní jámy s odvaly v západní části důlního areálu, viz obr. 2:1. Foto P. Hrubý.

Abb. 3. Abbaugruben mit Halden im Westteil des Grubenareals, siehe Abb. 2:1. Foto P. Hrubý.

Počáteční fáze exkavace roku 2016 zapadala do koncepce projektu Historické využívání krajiny Českomoravské vrchoviny v pravěku a středověku (DF13P01OVV005) i do dlouhodobého studia středověké produkce kovů na Českomoravské vrchovině (Hrubý-Hejhal-Malý 2007; Hrubý a kol. 2012; 2014). Prvotním vědeckým cílem kampaně bylo detailní poznání stratigrafie a struktury haldy, včetně získání geochemických a mineralogických dat. Dalším cílem bylo získání kvalitního souboru movitých artefaktů a víceméně očekávaná detekce konstrukčních reliktů technického zařízení. S tím byl přirozeně spojen cíl získat co největší soubor dendrochronologických dat. V průběhu exkavace se ukázalo, že část sedimentů má i dobrý archeobotanický potenciál, takže dalším z cílů bylo studium paleoekologického záznamu.

Výzkum přináší nové a zajímavé poznatky v otázkách mýcení lesů a proměn středověké krajiny. Prohlubuje poznání konkrétních technologií úpravy polymetalických rud. V tomto směru se ukázalo, že významným zdrojem dat je úpravnický odpad. S novými konkrétními poznatky výzkum znovu otevírá otázku pohonu rudních mlýnů v českém prostředí ve 13. století vodním kolem. Výzkumné aktivity se jen okrajově věnovaly otázce sídliště, jehož přítomnost se však předpokládá a $\mathrm{k}$ jehož lokalizaci může přispět prostorové vyhodnocení kovových nálezů (obr. 23).

\section{Topografie lokality a terénní relikty důlních i zpracovatelských aktivit}

\subsection{Těžební areál}

Asi 1200 m jižně od Koječína se v zalesněném území nachází starý těžební komplex čítající dnes přes 161 jam. Hlavní pásmo délky $1600 \mathrm{~m}$ se rozprostírá i na východním břehu Nohavického potoka, na katastrálních územích Úsobí a Dobrohostov. Směr pásma je ZSZ-VJV (azimut $100^{\circ}$ ). Na západním břehu potoka dosahuje hlavní důlní pásmo délky $1100 \mathrm{~m}$, na východním pak $500 \mathrm{~m}$. I s vedlejšími jámovými tahy činí šiřka důlního areálu v severozápadní části až $150 \mathrm{~m}$. Celková plošná výměra dochovaného areálu je 8,68 ha (obr. 1 a 2). Typicky trychtýřovitá ústí největších jam s mohutnými odvaly na hlavním tahu dosahují průměrů 16-18 m (obr. 2:1, obr. 3). Pokus o rozlišení důlních polí s aplikací historických důlních měr ve struktuře terénních reliktů zatím uskutečněn nebyl (např. Večeřa 2004; Vosáhlo 1996). Přesto lze uvažovat o nejméně třech 
a nejvíce pěti důlních mírách na západním břehu a o jedné důlní míře na východním břehu potoka.

Hlavní tah je doprovázen kratšími liniemi menších jam ve směru jeho průběhu i příčně na na něj. S opatrností lze hovořit o pozůstatcích průzkumných lánů, popř́ípadě pokusné těžbě. Jedna soustava o dvou liniích se rozprostírá severně od hlavního tahu a je s ním souběžná (obr. 2:2). Délka je $360 \mathrm{~m}$ a šiřka okolo $50 \mathrm{~m}$. Výrazná je i $115 \mathrm{~m}$ dlouhá linie deseti menších jam ve směru SSZ-JJV (azimut $165^{\circ}$ ) jižně od hlavního tahu (obr. 2:3). Nakonec lze v celém prostoru rozlišit malé prospekční jámy (o průměrech 1-3 m), často bez viditelného odvalu.

Specifický je úsek asi $220 \mathrm{~m}$ od západního břehu potoka, kde reliéf vytváŕí depresi s prameništěm. Na rozhraní dna a mírného svahu se kromě několika jam nachází antropogenní struktura nejasného stáří, ale téměř jistě hornického původu. Jedná se o liniový zářez s rovnoměrnými odvaly na bocích, hlavní osou nasměrovaný po svahu k potoku (obr. 2:4).

\section{2 Úpravnický areál}

Mezi důlními jámami a Nohavickým potokem se na levém břehu v délce asi $80-100$ m podél řečiště nalézají kumulace technogenních uloženin složené z hlušiny, rudniny i úpravnického odpadu. Nadmořská výška areálu je v rozmezí 509-506 m. Podle císařského otisku stabilního katastru (č. 3251-1) se zde v první polovině 19. století nacházela suchá louka, jejíž rozsah by mohl být sekundárním indikátorem hald, a tedy i někdejšího úpravnického areálu.

Technogenní uloženiny jsou v reliéfu nivy pod lesním porostem patrné jen v př́ípadě zkoumané haldy (profil 1) v nejjižnějším úseku areálu. Jinde jsou sneseny vodní erozí či starší zemědělskou činností a jsou patrné jako zvýšená niveleta břehu (obr. 4). Na východním břehu nebyly ani po opakované prospekci, zahrnující mikrosondáže a půdní vrty, technogenní uloženiny zjištěny. Hlušina a další technogenní výplně byly pomocí půdního vrtáku zachyceny na západním břehu potoka až do vzdálenosti $12 \mathrm{~m}$ od řečiště, kde vykliňují. Výška zkoumané haldy, která je z pozorovaných reliktů této kategorie nejvýraznější, se nad hladinou potoka se pohybuje okolo 1,6-1,8 m. Těleso je situováno na západním okraji starého a dnes již zaneseného a zarostlého pravotočivého ramene. Severní okraj haldy je př́ímo omýván potokem (obr. 4 a 5).

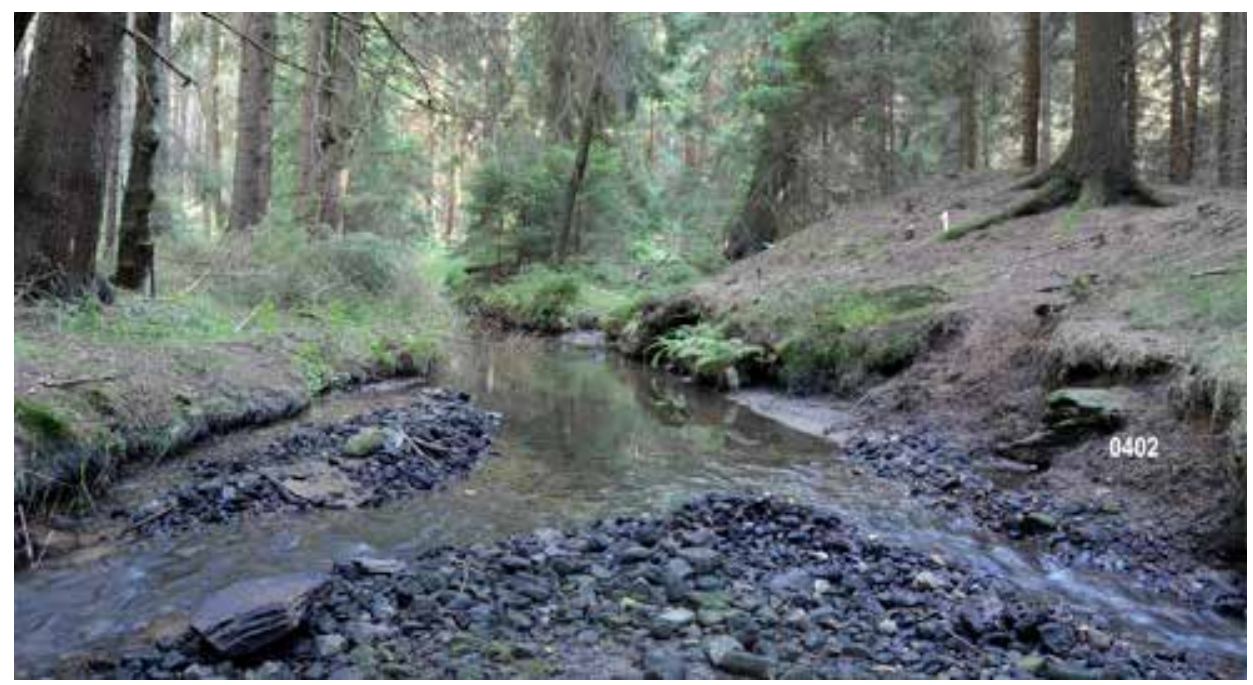

Obr. 4. Nohavický potok ve středověkém úpravnickém areálu. 1 - halda rudniny s profilem 1 . Na bázi je smýcené jedlové dřevo 0402. Foto P. Hrubý.

Abb. 4. Bach Nohavický potok im mittelalterlichen Aufbereitungsareal. 1 - Roherzhalde mit Profil 1. An der Basis der Halde befindet sich das gefällte Tannenholz 0402. Foto P. Hrubý. 


\subsection{Reliéf, geologické, půdní a rudní poměry}

Západní část důlního areálu přechází přes hřbet s kótami Jámy (588,0 m) a U lípy (597,9 m), přičemž relikty jam s odvaly dosahují maximální nadmořské výšky $585 \mathrm{~m}$. Nejnižší bod s výškou $508 \mathrm{~m}$ je vázán na koryto potoka. Hlavní jámové pásmo se rozprostírá po hřbetu svažujícím se k jihovýchodu, přičemž na jeho severní straně se od určitého úseku vytváŕí terénní deprese, která se asi $250 \mathrm{~m}$ západně od potoka prohlubuje a rozšiřuje v pramennou pánev. Krajinný reliéf je členitější jižně od studovaného úpravnického areálu. Zde se nalézají rozvětralé skalní výchozy (obr. 2). Údolí zde vyplňují pole balvanů roztroušených kryogenním zvětráváním.

Území se nachází v centrálním moldanubickém plutonu. V rámci Humpolecké vrchoviny patří do podcelku Herálecká vrchovina. Geologickým podkladem je drobnozrnný žilný granit,

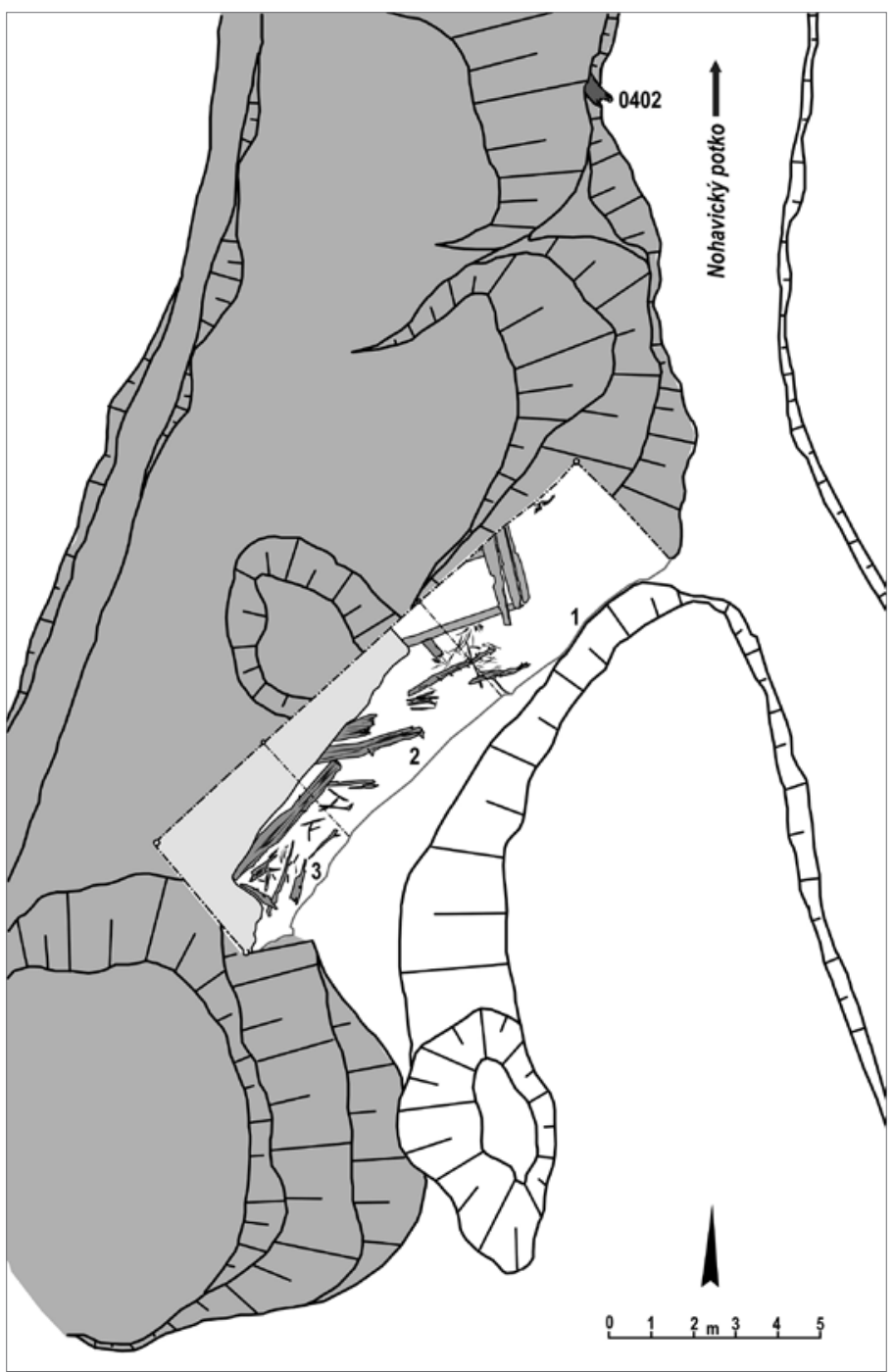

Obr. 5. Halda rudniny s profilem 1. Zaměření a grafika P. Hrubý.

Abb. 5. Roherzhalde mit Profil 1. Vermessung und Grafik P. Hrubý. 
území směrem k východu jsou tvořena sillimanit-biotitickými a cordierit-silimanitickými pararulami až migmatity (Cháb-Stráník-Eliáš 2007). Ve výše položených částech lokality se nalézají mezobazické kambizemě, na svazích dystrické kambizemě. Ve vazbě na potoční nivu převládají modální gleje a v úzké vazbě na řečiště pak fluviální sedimenty (Půdní mapa $1: 10$ 000, list č. 23-21-23).

Lokalita je součástí havlíčkobroského rudního revíru. Polymetalické mineralizace jsou řazeny k typu k-pol nebo ke spodnopermskému Fe-Zn-Pb-Ag zrudnění typu Kutná Hora (Bernard 1991). Nejbližší lokality historické těžby jsou od zájmového území vzdáleny 7 km severovýchodně. Lokalita Koječín však sousedí i s oblastí primární zlatonosné mineralizace u Humpolce, která je vzdálena 7 km západně (Litochleb 1981; Litochleb-Malec-Sztacho 1982; Losertová a kol. 2011).

\section{Metody terénního i dálkového průzkumu, exkavace a dokumentace}

\subsection{Výzkum haldy úpravnického odpadu: profil 1}

Na západním břehu potoka byly zkoumány tři profily, které byly s odstupem desítek metrů rozmístěny po celém úseku potoka s pozorovanými technogenními uloženinami a smýcenými dřevy. Zatímco profily 2 a 3 ve střední a severní části areálu mají charakter malých odběrových profilů, profil 1, kterým se tato práce bude zabývat, lze již považovat za sondáž úpravnické haldy. Rozsah exkavace v iniciační fázi roku 2016 byl malý, délka činila $3 \mathrm{~m}$, výška $1 \mathrm{~m}$ a šiřka rovněž $1 \mathrm{~m}$. Roku 2017 byl řez rozš́iřen na tři pětimetrové úseky označené jako čtverce 1-3, které v omezených podmínkách umožňovaly i plošnou exkavaci (obr. 5-7). Práce v trvale zvodněném prostředí v kontaktu s řečištěm vyžadují udržování odtoku vody příkopem.

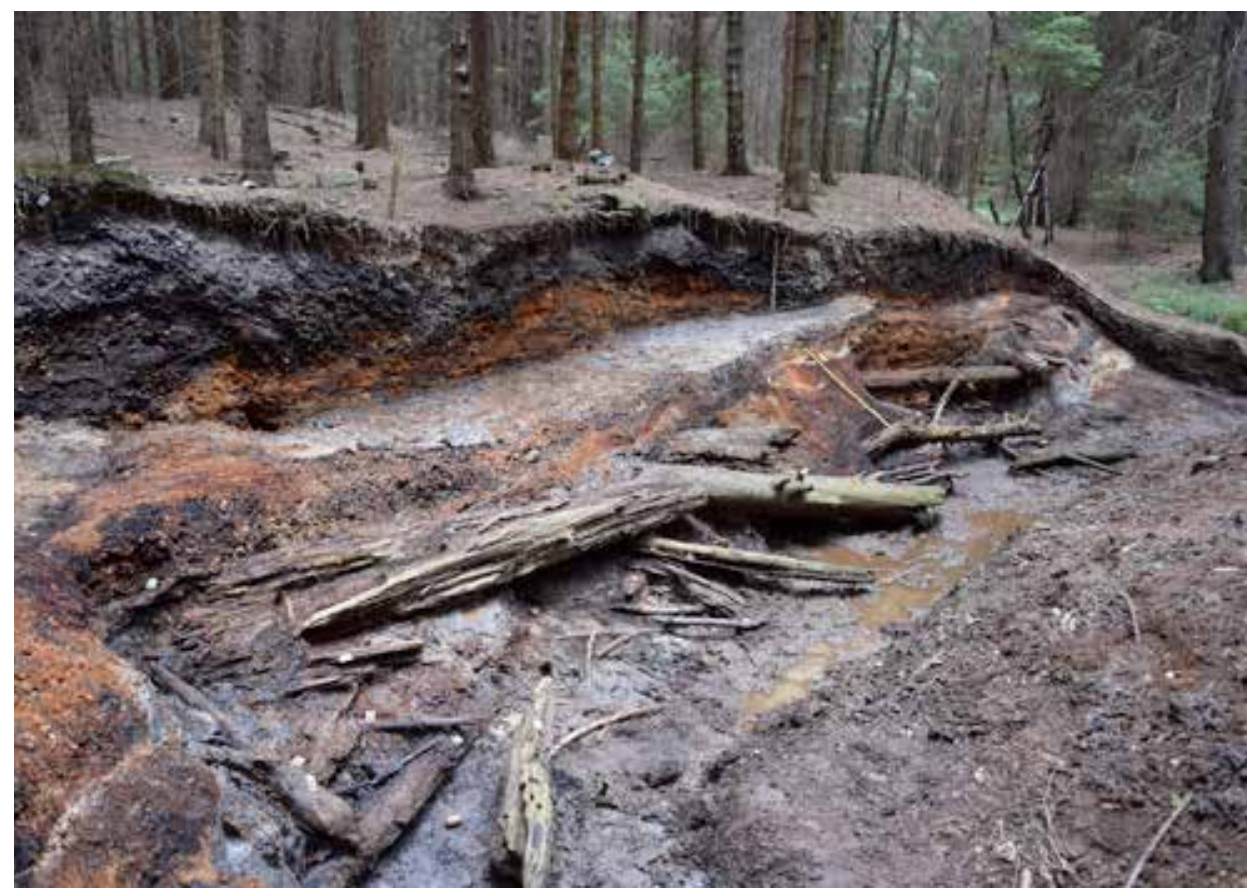

Obr. 6. Profil 1, stav v roce 2018. Foto P. Hrubý.

Abb. 6. Profil 1, Zustand im Jahr 2018. Foto P. Hrubý. 

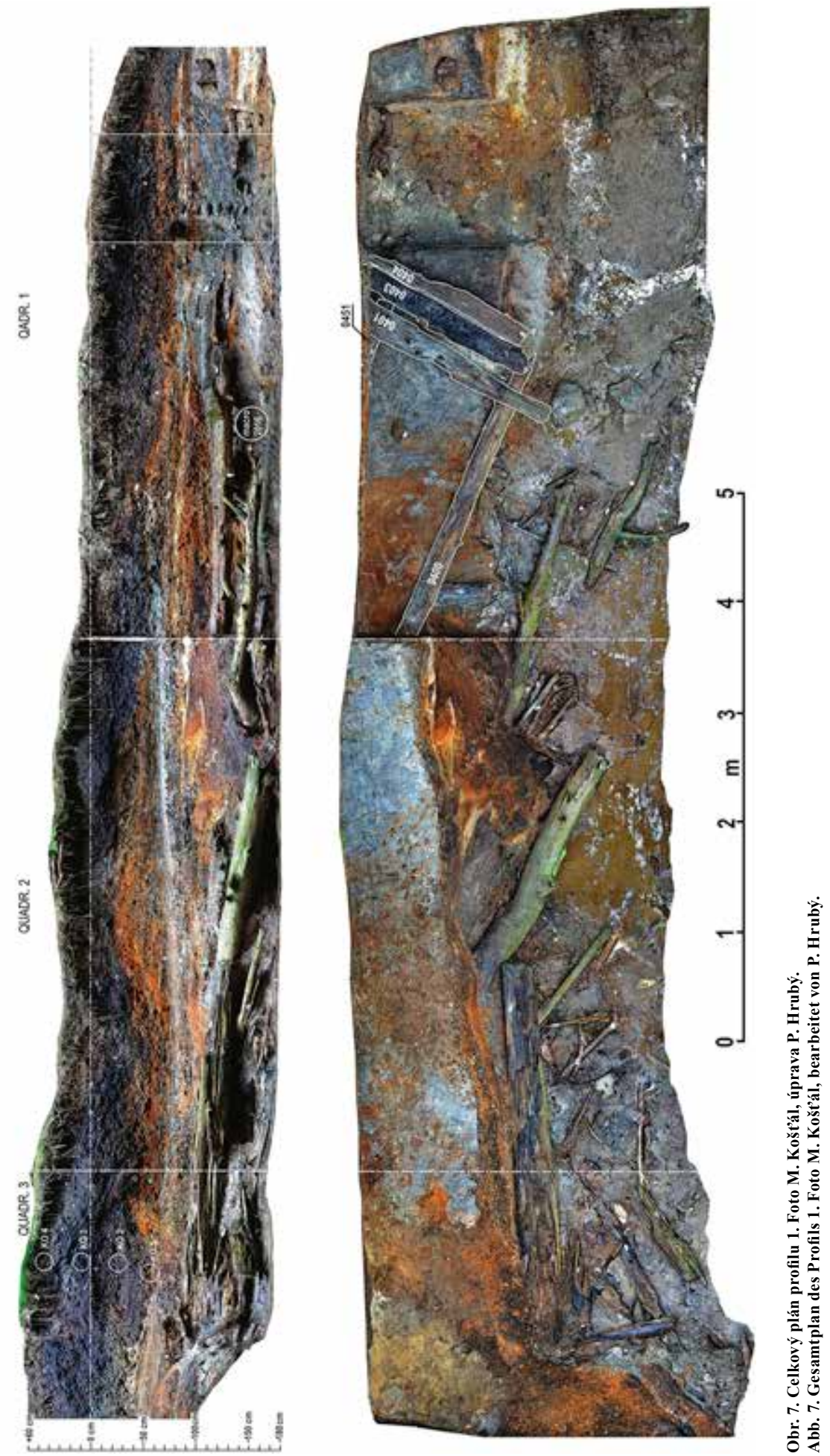


\subsection{Detektorový průzkum montánního areálu v lesním prostředí}

V blízkosti úpravnických hald i na jámových tazích byl v dubnu 2017 v souvislosti se sondážemi proveden dokumentovaný detektorový průzkum. Rozvinul se v údolí potoka, dále v bočním údolí západně od potoka (obr. 2:4) a zejména na východním břehu vodoteče (obr. 23). Západní část areálu je pokryta hustým lesním porostem a kromě toho jsou zde některé z důlních jam zaváženy recentním kovovým odpadem. Obě okolnosti účinnému detektorovému průzkumu značně brání.

Cílem průzkumu bylo upřesnění chronologického rámce lokality a detekce sídlištních a případně i dosud neznámých zpracovatelských areálů vázaných na důlní pracoviště. Dalším cílem byla záchrana kovových artefaktů před nekontrolovaným detektorovým rabováním. Použitá technika byla zastoupena škálou analogových i digitálních detektorů kovů. Charakter území umožňoval lokalizaci artefaktů středních i menších rozměrů. Srovnatelné zpracovatelské areály, jako třeba důlní centrum Buchberg na Přibyslavsku nebo Vyskytná na Pelhřimovsku, jsou z velké části kontaminovány hutním odpadem, a vyžadují proto vy̌̌ší odladění mineralizace půdy i selekci rušivých signálů, obojí na úkor detekce drobných nálezů.

Prospekce byla provedena v počtu 15 až 20 prospektorů. Území bylo rozděleno na dva prrirozené polygony západně a východně od vodoteče, kterým byl při terénní prospekci věnován přibližně stejně dlouhý čas. $\mathrm{V}$ polygonech se hledači pohybovali volně. V členitém terénu a v lesním prostředí s nestejnorodou vegetací se při vyšším počtu hledačů tato strategie ukazuje jako mnohem účinnější než procházení v pásech, popřípadě ve čtvercích. Nálezy byly vždy po vykopání označeny praporky. Následně byly systematicky sáčkovány a popisovány tř́člennou dokumentační skupinou. Souřadnice byly stanovovány ruční GPS na telefonním př́istroji Lumia 640 se záznamem polohy při focení artefaktu. Standardní přesnost lokalizace byla vyvážena rychlostí sběru dat, při kterém odpadla nutnost odděleného fotografování předmětů v místě vyzvednutí ze země. Bylo získáno 80 stř̌edověkých, 38 novověkých a 27 nedatovaných předmětů (kap. 8.5).

\subsection{Metody dokumentace a zpracování prostorových dat}

Lokalita se nachází v náročném terénu - jde o potoční údolí pokryté hustým lesním porostem a nejbližší geodetický bod je vzdálený asi $2 \mathrm{~km}$. Proto byl použit lokální koordinační systém s orientací dle magnetického severu. To zahrnovalo čtyři orientační body, jejichž prostřednictvím bylo možné provést následné zaměření v S-JTSK i polohové korekce. Metoda umožnila měnit stanoviště přístroje (Leica TS06) se zachováním kontinuity zaměření v prostoru. Výškové rozdíly sondovaného prostoru nedovolovaly přímou dokumentaci pomocí ortofotografií s obvyklým využitím GIS prostředí ArcMap ke georeferenci a sloučení fotografií. Dokumentace odkrývaných struktur tak byla prováděna metodou 3D fotogrammetrie - IbM (Image based Modelling) za využití počítačového vidění SfM (Structure from Motion). Snímkování počítalo s hodnotou GSD (Ground Sample Distance) asi $0,5 \mathrm{~cm}$ u každého snímku tak, aby bylo možné zachytit strukturu i barevnou škálu. Výpočet probíhal v software Agisoft Photoscan 3D (Leachtenauer-Driggers 2001, 30-32; Štuhec-Zachar 2017, 39, 42). Z výsledného modelu byly vytvořeny dva dokumentační pohledy (obr. 7).

Pro vizualizaci reliktů důlní a úpravnické činnosti byla využita data digitálního modelu 5. generace ČÚZK. Interpolační metodou nearest neighbour o velikosti pixelu $0,25 \mathrm{~m}$ v prostředí GIS a vizualizačním přepočtem v softwaru Relief Vizualization Toolbox byly získány styly vizualizace (Sibson 1981, 21-36; Holata-Plzák 2013, 66; Zakšek-Oštir-Kolaj 2011). Ty byly v prostředí GIS prolnuty do výsledného kompozitu. Kriticky je nutné počítat s tím, že zejména u malých antropogenních reliktů mohly kvůli lesnímu prostu a detailu interpolace vzniknout chyby. 


\section{Metody zpracování a analýz archeometalurgických nálezů}

\subsection{Půdní vzorky na geochemický rozbor (půdní metalometrie)}

Geochemické rozbory potočních profilů s komponenty důlní činnosti, úpravy a hutnictví rud patří mezi standardní postupy. V minulosti byly úspěšně provedeny u České Bělé nebo na Koželužském potoce u Jihlavy (Hrubý a kol. 2014, 85-89, 90-91, 143-147). Na Nohavickém potoce byly půdní vzorky odebrány ve sloupci po $10 \mathrm{~cm}$ v množství okolo $0,5 \mathrm{~kg}$. Po vysušení při pokojové teplotě byly sítovány na sítě s oky o průměru $2 \mathrm{~mm}$. Podsítná frakce byla vysušena při teplotě $95^{\circ} \mathrm{C}$ a kvartací z ní byl odebrán vzorek pro analýzu. Ten byl vařen v kyselině dusičné, filtrát byl analyzován metodou AAS na spektrometru Solar M5 (TJA Solutions) v Ústavu geologických věd PřF MU, Brno (analytik P. Kadlec).

\subsection{Vzorky rudniny a olověný slitek}

Vzorky rudniny měly velikost od několika centimetrů do $15 \mathrm{~cm}$. Byly z nich zhotoveny nábrusy, které byly zkoumány v optickém mikroskopu v odraženém světle a v elektronovém rastrovacím mikroskopu (JEOL JSM-6490LV s EDX analyzátorem, Ústav geologických věd PřF MU, Brno, analytik J. Štelcl; srov. obr. 15). Vzhledem k tomu, že přitom byla zjištěna řada chemicky komplikovaných minerálních fází, byly vybrané vzorky dále analyzovány na elektronové mikrosondě CAMECA SX 100 (NM Praha, analytik Z. Dolníček). Výsledky těchto WD analýz jsou nyní zpracovávány.

Pro chemickou charakteristiku rudniny byly vybrané vzorky podrceny a ručně z nich byly vytrríděny na sulfidy nejbohatší partie. V takto získaném materiálu byl po rozkladu stanoven obsah vybraných kovů metodou AAS na spektrometru Solar M5 (TJA Solutions) v Ústavu geologických věd PřF MU, Brno (analytik P. Kadlec). Obsah Sn byl stanoven metodou ICP na přístroji iCAP 6500 na Katedře analytické chemie PřF MU, Brno (analytik L. Simoníková).

Analyzován byl také diskovitý slitek olova (obr. 17:2). Byl podroben XRF analýze (ruční XRF analyzátor Vanta, doba načítání spektra 30 s) a následně i EDX analýze v elektronovém mikroskopu (analýza K. Malý).

\section{Terénní archeologická situace profilu 1}

\subsection{Rudnina se znaky primární úpravy}

Půdní kryt tvoří lesní půda s rozprostřeným kořenovým systémem smrčí (vrstva 0101). Pod ní se v hloubkách $10-80 \mathrm{~cm}$ v celém zkoumaném rozsahu nacházely nesoudržné vrstvy velikostně upravené rudniny (vrstvy 0102, 0103 A-E). Svrchní část $(10-60 \mathrm{~cm})$ byla tvořena frakcí v rozmezí $3-5 \mathrm{~cm}$, popřípadě $6-9 \mathrm{~cm}$, výjimečně až $15 \mathrm{~cm}$. Povrch těchto fragmentů byl zbarven tmavě, což je zapříčiněno vysráženými hydroxidy, sírany, uhličitany a případně i fosfáty železa a manganu. Průběh těchto vrstev rudniny není lineární a vodorovný, naopak na řezu vytváří kresbu tř́ kumulací, které se ostatně dodnes projevují i v samotném reliéfu. Spodní část této sekvence v hloubkách $60-80 \mathrm{~cm}$ má jemnější frakci, zpravidla $2-3 \mathrm{~cm}$, a je více prostoupena jemnou komponentou. Zároveň je zřetelně světlejší a převažují v ní hnědé až rezavé odstíny (obr. 7,8 a 12). V těchto uloženinách bylo obsaženo nejvíce zlomků středověké keramiky (obr. 18 a 19).

\subsection{Technogenní sedimenty se znaky mletí a praní}

Pod tímto horizontem se nalézala velmi pestrá sekvence uloženin, tvořených zpravidla jemnozrnnou rudninou (vrstvy 0104, 0105, 0107, 0113, 0116). Zrna jsou ostrohranná a frakce vrstev se zdá být jednotná. Hlavním znakem těchto sedimentů, které byly na základě morfologických 

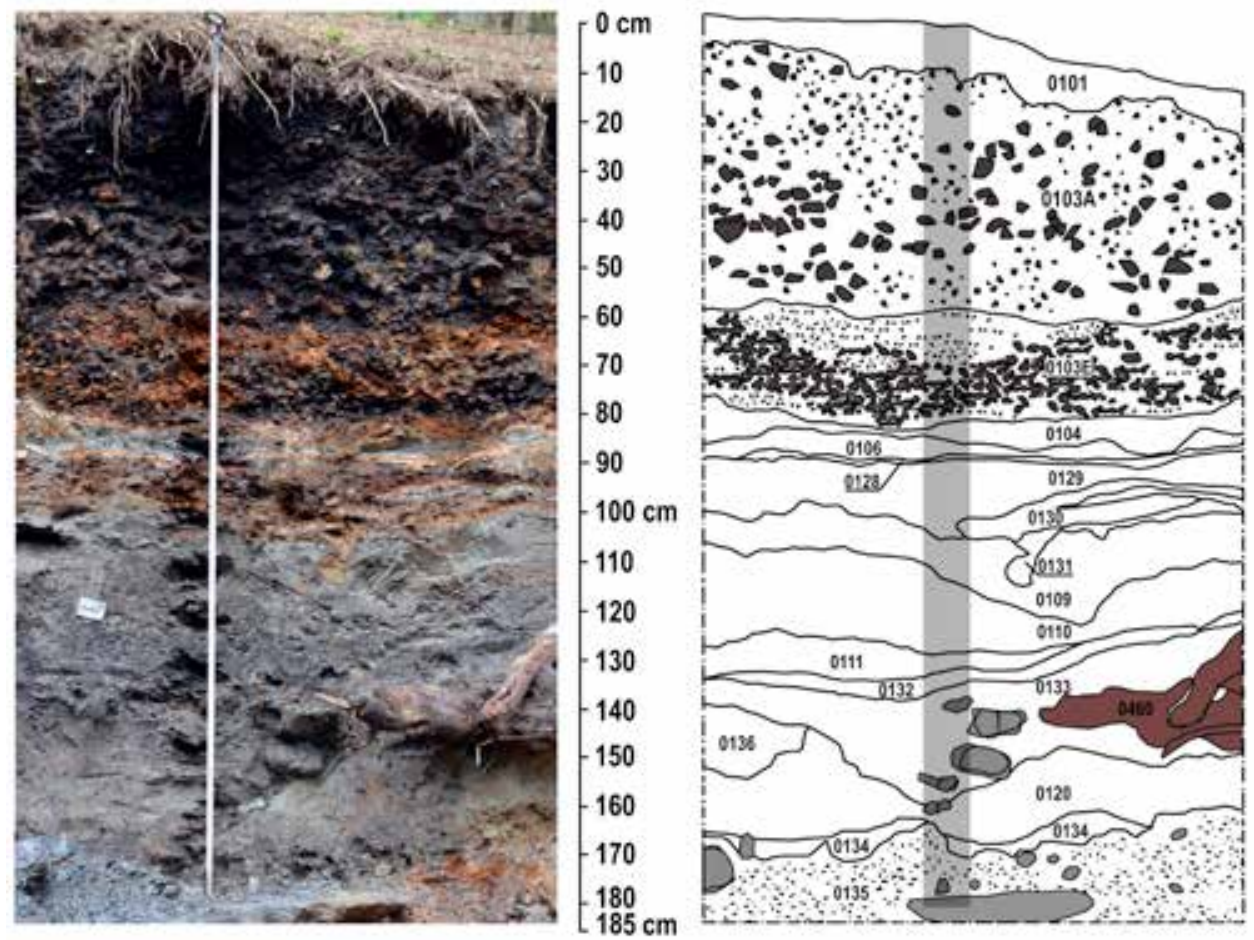

Obr. 8. Vzorkovaný úsek profilu 1 ve čtverci 1 . Foto a grafika $P$. Hrubý.

Abb. 8. Durch Probenentnahme analysierter Abschnitt von Profil 1 im Planum 1. Foto und Grafik P. Hrubý.

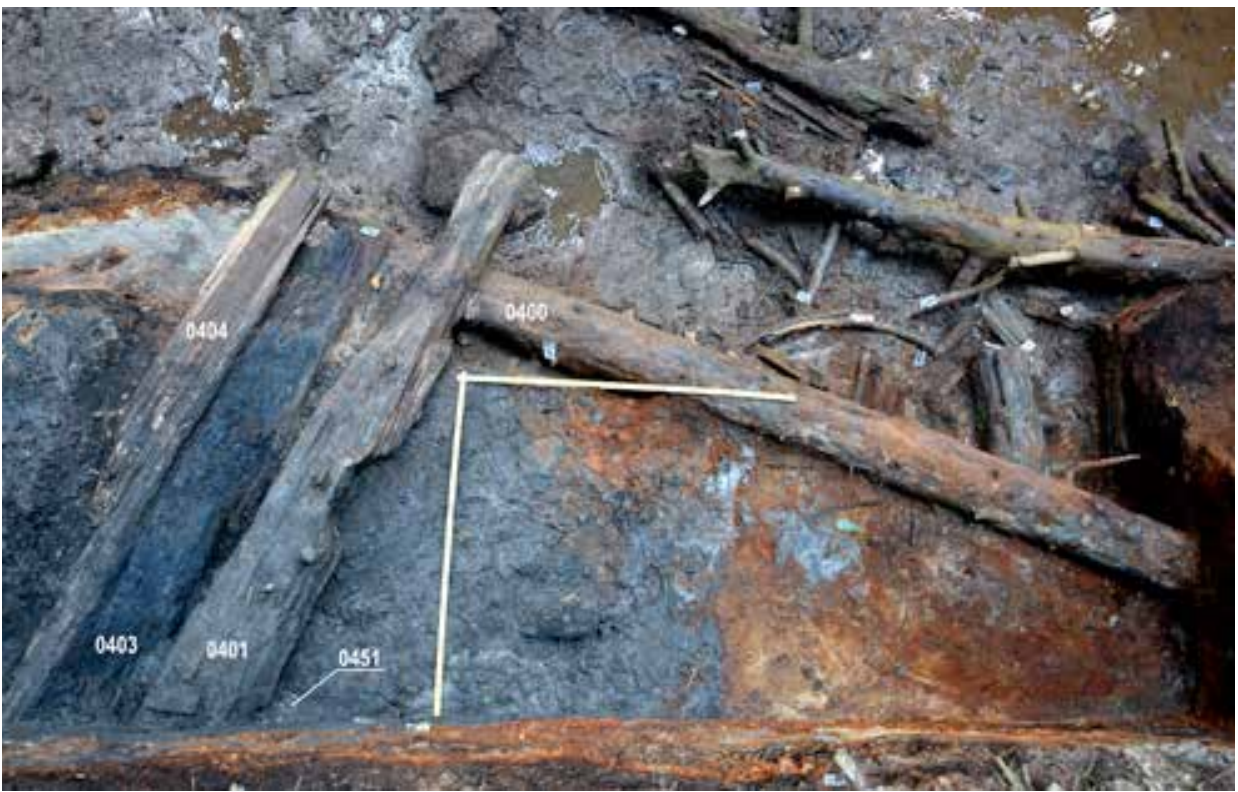

Obr. 9. Dřevěné stavební prvky. Foto P. Hrubý.

Abb. 9. Bauelemente aus Holz. Foto P. Hrubý. 


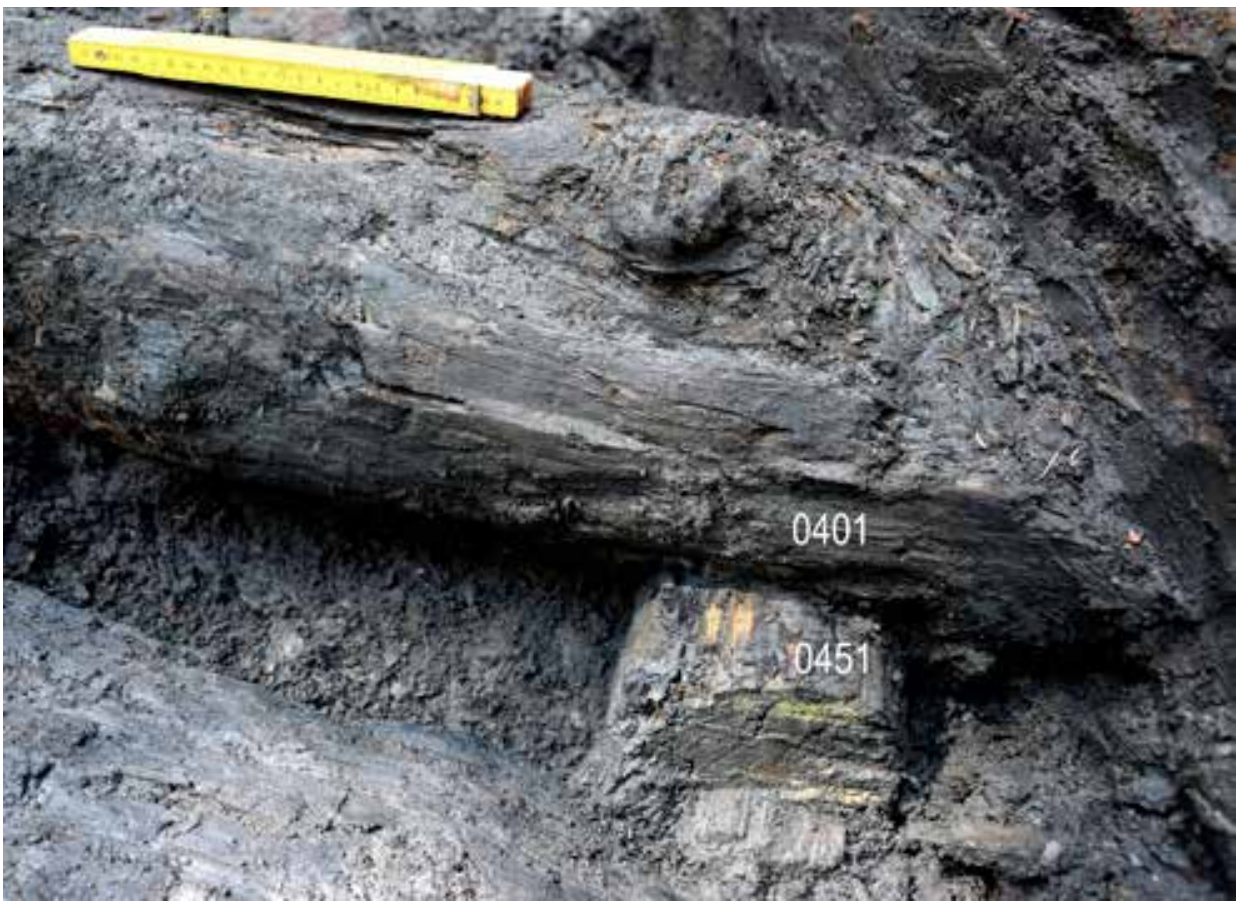

Obr. 10. Detail spoje dvou dřevěných prvků. Foto P. Hrubý.

Abb. 10. Detail einer Verbindung zweier Holzelemente. Foto P. Hrubý.
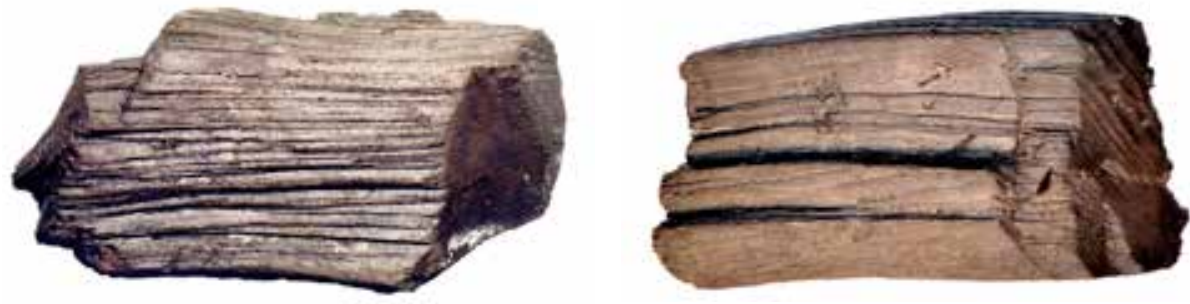

\section{2 en ? 4 ,}

3

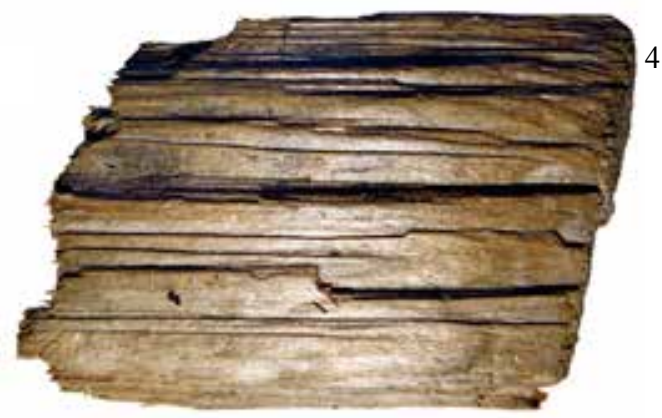

Obr. 11. Dřevěné odštěpky z vrstev mezi smýcenými dřevy. Foto P. Hrubý.

Abb. 11. Holzsplitter aus den Schichten mit gerodetem Holz. Foto P. Hrubý. 


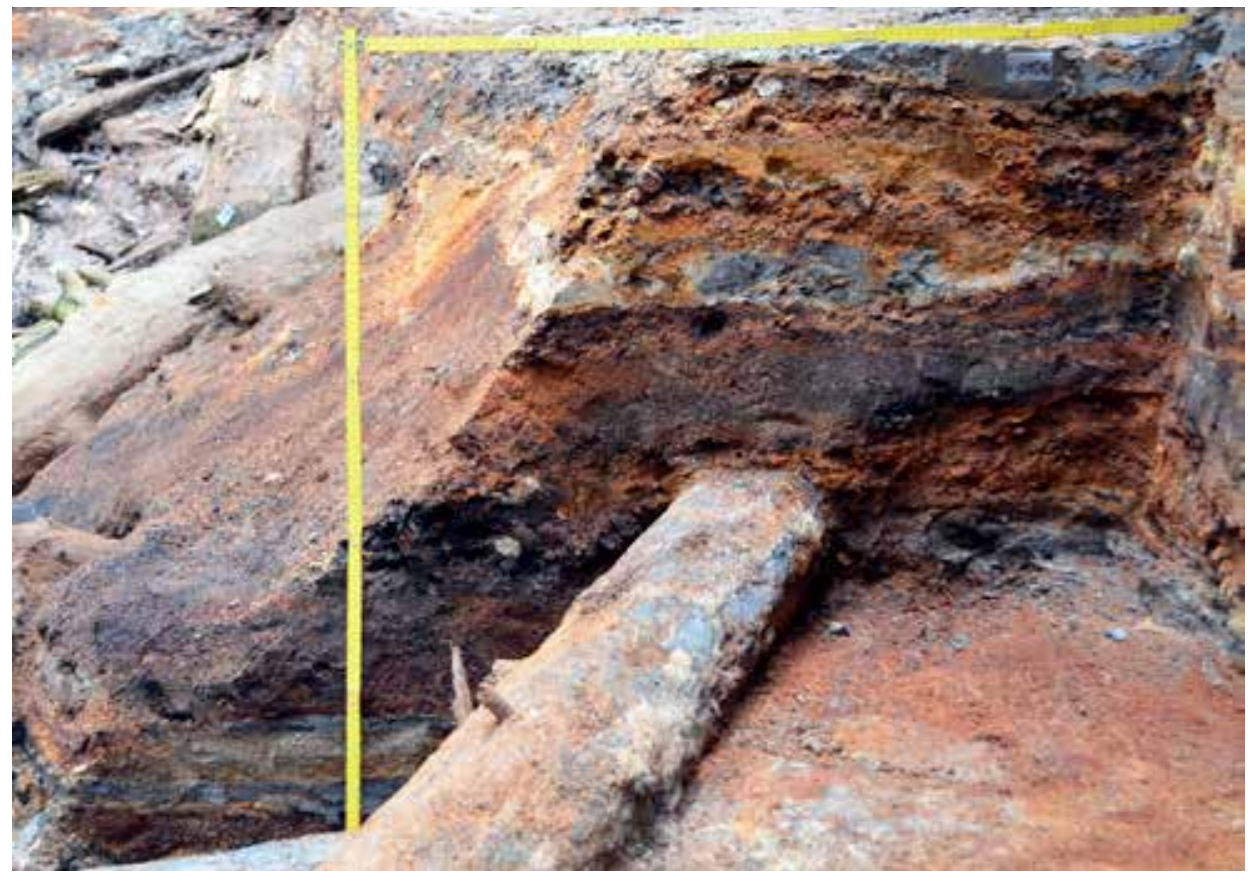

Obr. 12. Sedimenty mleté rudniny na profilu 1. Foto P. Hrubý.

Abb. 12. Sedimente von gemahlenem Roherz in Profil 1. Foto P. Hrubý.

a strukturních vlastností evidovány jako samostatné stratigrafické jednotky, je jejich velké množství a často jen lokální výskyt. Některé z těchto sedimentů byly vlivem sekundárních chemických procesů velmi ztvrdlé. Některé obsahovaly menšinovou příměs plastické komponenty. Charakteristická je přítomnost malých zlomků uhlíků a keramiky. V severní části čtverce 1 byla tato souvrství pozorována $\mathrm{v}$ hloubkách $80-110 \mathrm{~cm}$. V jižní části čtverce a v přilehlé části čtverce 2 však tyto sedimenty vyplňovaly přirozenou terénní depresi a dosahovaly hloubek až $160 \mathrm{~cm}$ (obr. 7-9).

Popisované vrstvy jsou prostoupeny plastickými anaerobními uloženinami rovněž technogenního původu. Na jejich vzniku se podílela vodní sedimentace, spojená pravděpodobně s řízenými pracovními procesy. Někdy mohou obsahovat viditelnou př́měs jemně mleté rudniny (vrstvy 0106, 0108, 0109, 0110, 0111). V těchto uloženinách, zpravidla zbarvených šedě byly př́itomny uhlíky. Byly v nich nalezeny odřezky a dílce kůží a pochází odsud i ojedinělý útržek textilu (obr. 20 a 21). Specifická byla celoplošně pozorovaná vrstva 0106 . Vytváŕí ve čtvercích 2 , 3 a v přilehlé části čtverce 1 souvislou platformu, která není sice zcela vodorovná, přesto má charakter určité pracovní (pochozí) úrovně (obr. 6 a 7). Kromě uhlíků obsahovala i zvířecí srst (obr. 22) a peří. V těchto uloženinách naopak nebyly obsaženy prakticky žádné keramické nálezy.

\subsection{Konstrukční dřeva}

Zmíněné sedimenty překrývaly i prostupovaly konstrukční jedlová dřeva 0400, 0401, 0403, 0404 a 0451 (obr. 7, 9 a 10). Od dřev považovaných za smýcený lesní porost se tato skupina lišila tím, že dřeva byla odkorněna a zbavena větví. Hlavním konstrukčním prvkem bylo dřevo 0401. Šlo o zčásti opálený a přitesaný jedlový kmen průměru maximálně $24 \mathrm{~cm}$. Na povrchu byl trapézovitý zádlab. Konec překrývající dřevo 0400 byl začepován, takže lze hovořit o spoji. Obě 
dřeva však vůči sobě nejsou v pravém úhlu (obr. 9). Spoj se nalézal i na opačném konci dřevěného dílce 0401 (obr. 10). Ke konstrukčním dřevům se řadí i štípané desky 0403 a 0404 (obě šiřrky 22-24 cm), položené ve stejné úrovni jako prvek 0401, s nímž jsou rovnoběžné. Deska 0403 byla v celé délce ohořelá. Posledním jistým konstrukčním prvkem je vodorovně položený odkorněný kuláč $0451 \mathrm{~s}$ průměrem $16 \mathrm{~cm}$. Zaujímá stejnou konstrukční pozici jako prvek 0400 , s nímž je rovnoběžný. Jejich vzájemná vzdálenost je $1,25 \mathrm{~m}$. Všechna tato dřeva jsou jedlová, u žádného $\mathrm{z}$ nich se nepodařilo změřit datum smýcení.

\subsection{Smýcený středověký lesní porost a sedimentární záznam před začátkem zpracovatelských aktivit}

Od hloubek $100-110 \mathrm{~cm}$ byly odkrývány smýcené, neuspořádaně ležící, neodvětvené a neodkorněné kmeny a kořeny (obr. 6 a 7). Do výzkumné sezóny 2018 bylo př́i exkavaci profilu 1 evidováno 38 dřev tohoto charakteru. Dokumentováno je 21 kmenů, deset odseknutých větví a dva odumřelé kořeny. Ve dvou případech lze kvůli pokročilé dekompozici hovořit pouze o nespecifikovaných dřevech. Na jedenácti dřevech byly stopy ohoření (většinou kmeny), stejný počet prvků nesl stopy sekyry, přičemž odseknutí bylo pozorováno i na všech velkých větvích. Čtyři dřeva nesla stopy ohoření i sekyry a v jednom př́ípadě (kmen) byly patrné stopy pily. Z patnácti analyzovaných dřev se pouze u sedmi vzorků na profilu 1 a jednoho na profilu 3 podařilo dendrochronologicky změřit datum smýcení (tab. 1). Jedná se o sérii dat z rozmezí let 1253/1254 až 1257/1258. Všechna analyzovaná dřeva jsou jedle (Kyncl 2018).

Tato dřeva byla na bázi prostoupena jemným plastickým sedimentem 0119 s vysokým podílem organických příměsí, jako jsou větvičky, odštěpky (obr. 11) a další makrozbytky. $Z$ těchto uloženin byl odebrán půdní vzorek objemu asi 101 na analýzu rostlinných makrozbytků (KočárKočárová 2017). Tento horizont přímo nasedá na pohřbený půdní typ $0133 \mathrm{~s}$ odumřelými kořeny (0460). Půdní horizont stratigraficky uzavírá holocenní bázi profilu, zastoupenou anorganickým sedimentem 0120. Pod touto úrovní byl ve čtverci 1 na stratigrafickém záznamu dochován ještě relikt nejstaršího půdního horizontu (obr. 8, vrstva 0134). Ten nasedal na nevytř́iěný anorganický štěrkovitý sediment $0135 \mathrm{~s}$ kameny zčásti omletými vodou.

\section{Geochemická charakteristika technogenních uloženin v profilu 1}

U klíčového profilu 1 je zjevné, že na jeho bázi v hloubkách $160-185 \mathrm{~cm}$ jsou obsahy sledovaných prvků ( $\mathrm{Zn}, \mathrm{Cu}, \mathrm{Sb}, \mathrm{Ag}, \mathrm{Pb}, \mathrm{As})$ nejnižší a v podstatě zanedbatelné. V úrovni deponie rudniny $(10-80 \mathrm{~cm})$ i v úrovni technogenních sedimentů se znaky mletí a praní $(80-130 \mathrm{~cm})$ jsou obsahy sledovaných kovů vysoké, místy až extrémně (obr. 13).

Odlišnou charakteristiku má As, i koeficienty korelace $s$ dalšími prvky jsou nejnižší $(0,13-0,40)$. Ostatní prvky mají charakteristiky přítomnosti v uloženinách obdobné. Nejvyšší

\begin{tabular}{|c|c|c|c|c|c|c|c|c|}
\hline Wood Nr. & section & format & sampled & Lab. ID & datum & method & rings & species \\
\hline 0402 & - & $\varnothing 55 \mathrm{~cm}$ & 26.04 .2016 & X3807 & $1254 / 1255$ & cutting & 174 & Abies \\
\hline 0406 & 1 & $\varnothing 18 \mathrm{~cm}$ & 26.04 .2016 & X3803 & $1254 / 1255$ & cutting & 56 & Abies \\
\hline 0410 & 1 & d. $35 \mathrm{~cm}$ & 26.08 .2016 & X3894 & $1254 / 1255$ & cutting & 95 & Abies \\
\hline 0413 & 1 & $\varnothing 40 \mathrm{~cm}$ & 01.09 .2018 & Y3241 & $1252 / 1253$ & cutting & 99 & Abies \\
\hline 0416 & 1 & $\varnothing 40 \mathrm{~cm}$ & 01.09 .2018 & Y3233a4 & $1254 / 1255$ & bore & 95 & Abies \\
\hline 0417 & 1 & $\varnothing 44 \mathrm{~cm}$ & 01.09 .2018 & Y3244 & $1254 / 1255$ & cutting & $54+8$ & Abies \\
\hline 0419 & 1 & $\varnothing 25-28 \mathrm{~cm}$ & 01.09 .2018 & Y3243 & $1254-1255$ & bore & $67+3-4$ & Abies \\
\hline 0453 & 3 & $\varnothing 50-60 \mathrm{~cm}$ & 01.09 .2018 & Y3240 & $1257 / 1258$ & bore & 184 & Abies \\
\hline
\end{tabular}

Tab. 1. Dendrochronologie vzorkovaných dřev. Podle Kyncl 2018.

Tab. 1. Dendrochronologie der anhand von Proben analysierten Hölzer. Nach Kyncl 2018. 

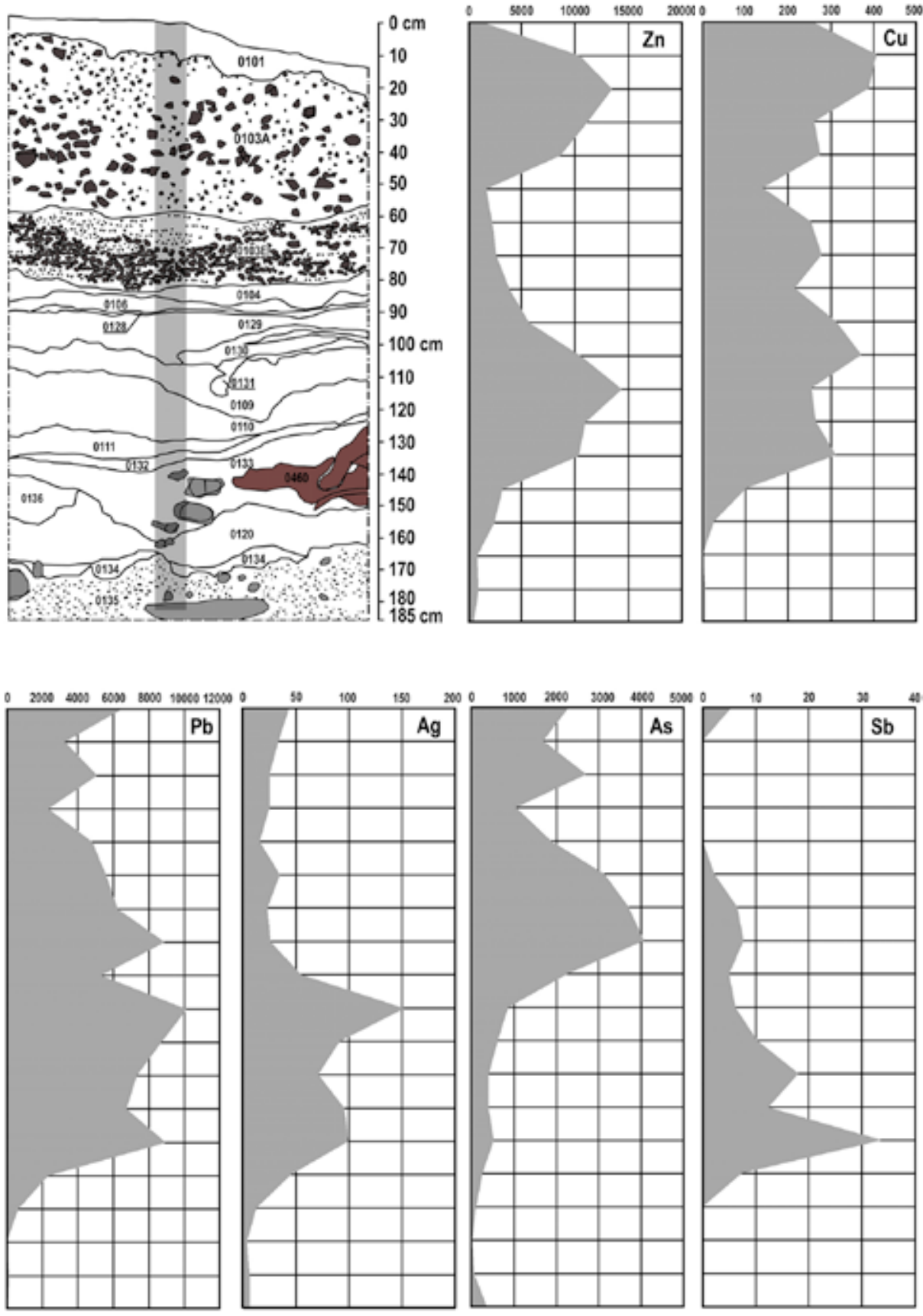

Obr. 13. Těžké prvky ve stratigrafickém záznamu profilu 1. Hodnoty v ppm. Abb. 13. Schwere Elemente in der Stratigraphie von Profil 1. Werte in ppm. 
koeficienty korelace jsou u $\mathrm{Pb}-\mathrm{Cu}(0,89)$ a $\mathrm{Ag}-\mathrm{Sb}(0,85)$. Svědčí to o společném vystupování těchto prvků v rudách, nebo přinejmenším o jejich společném postupu úpravnickým procesem. Naproti tomu rudy s podstatným obsahem As byly nejspíš separovány zvlášt'.

Maximální obsahy sledovaných prvků jsou na profilu 1 v hloubkách $95-130 \mathrm{~cm}$. Chování prvků v supergenních procesech je odlišné, nelze proto předpokládat, že jde o druhotné nabohacení haldového materiálu při migraci prvků. Sekvence profilu s nejvyššími obsahy sledovaných prvků reprezentuje zpracování nejbohatších rud, popřípadě nejvyšší intenzitu úpravnické činnosti. Nejvyšší obsahy zinku, až okolo 3 hmot. \% nejsou překvapující. Zinek neměl pro středověké hutníky význam a rudnina s jeho obsahem zůstávala na místě. Pozoruhodná jsou
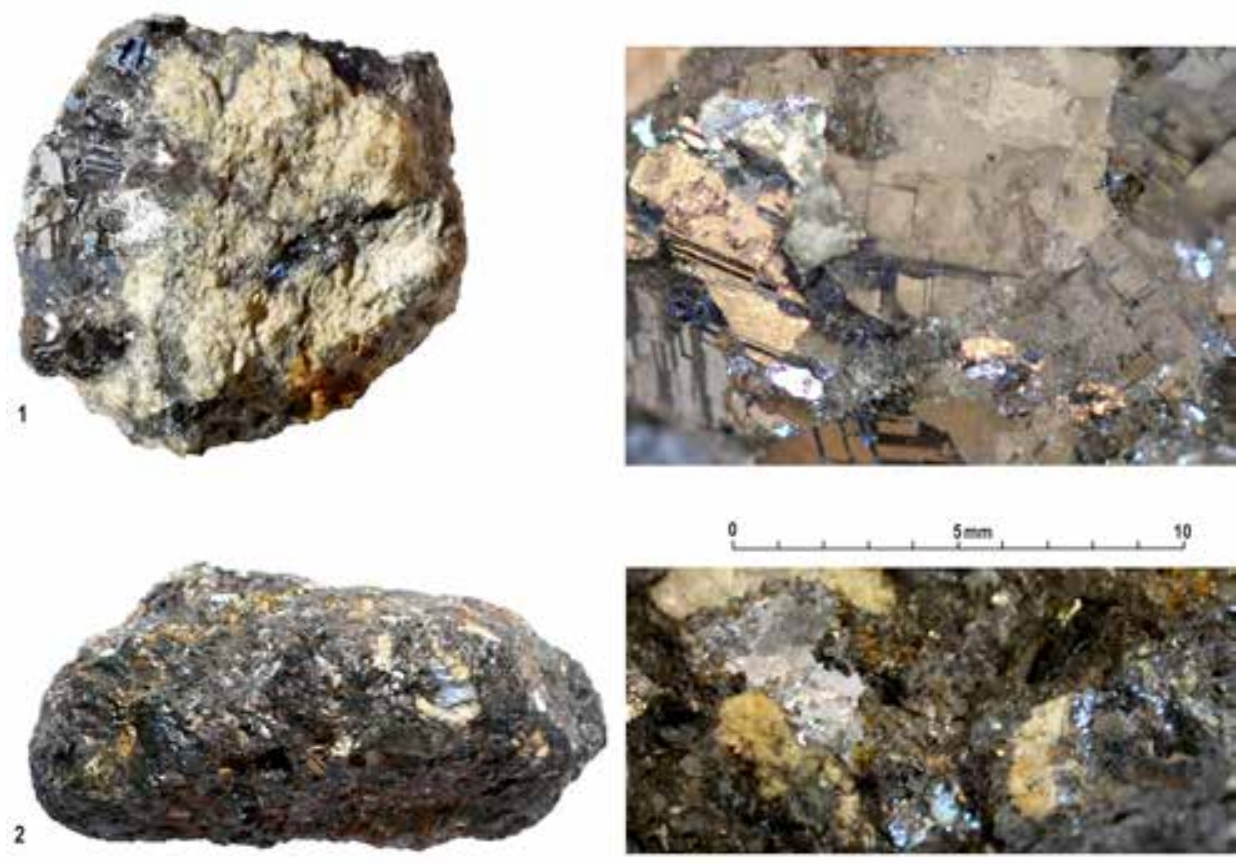

0
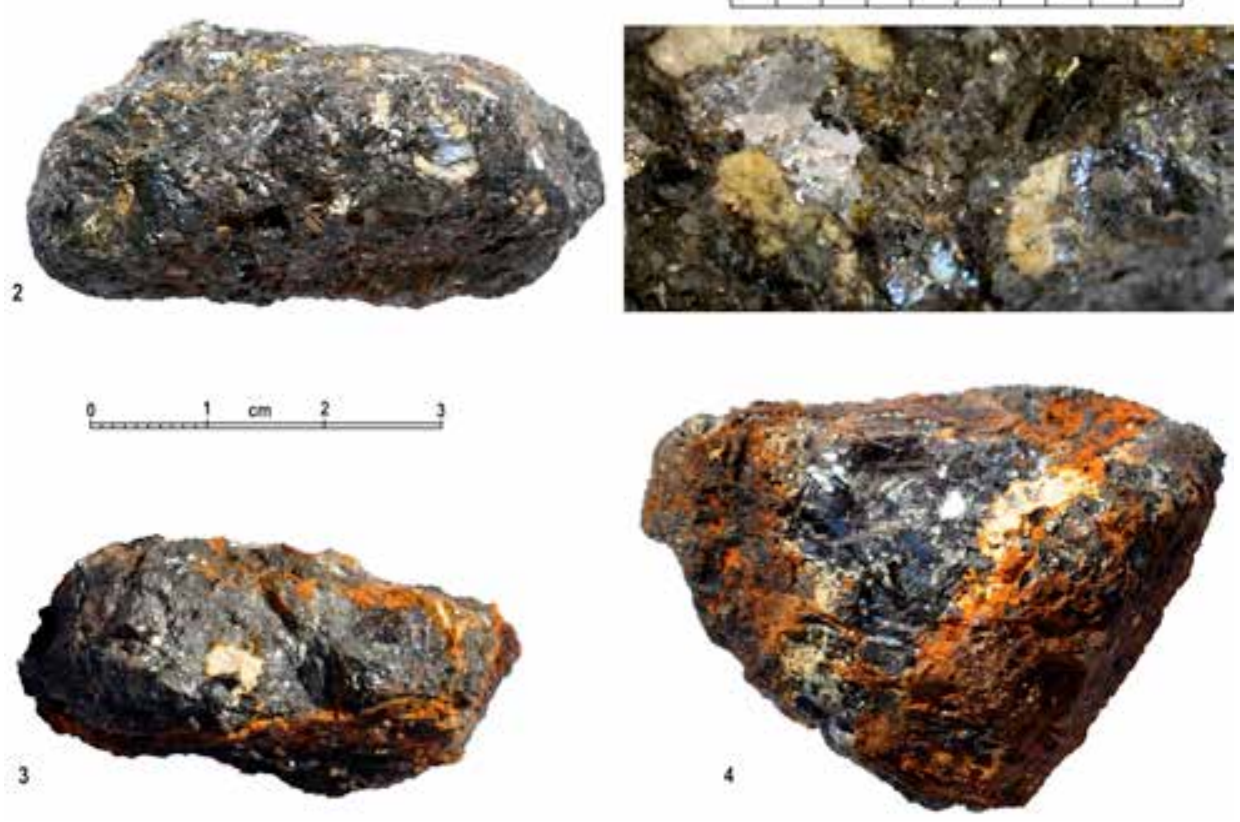

Obr. 14. Ruda $z$ deponie v areálu primární úpravy rud na břehu Nohavického potoka. 1 - galenit; 2 - sfalerit $s$ inkluzemi galenitu a pyritu; 3 a 4 -sfalerit. Foto P. Hrubý a P. Duffek.

Abb. 14. Erz von der Deponie im Areal der primären Erzaufbereitung am Ufer des Baches Nohavický potok. 1 - Galenit; 2 - Sphalerit mit Galenit- und Pyritinklusionen; 3 und 4 -Sphalerit. Foto P. Hrubý und P. Duffek. 


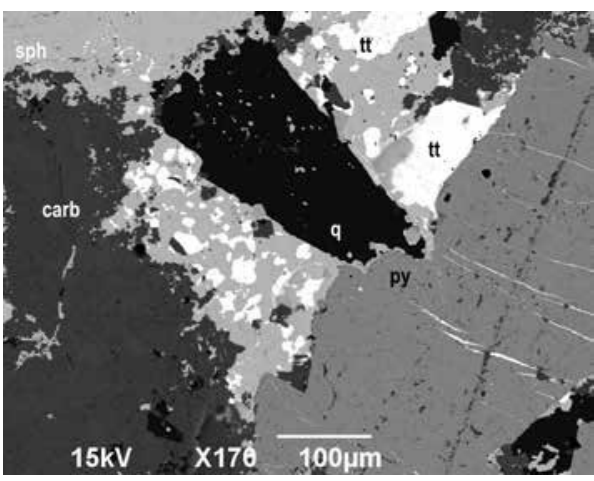

Obr. 15. Mikrofotografie rudniny, elektronový mikroskop, BSE. py - pyrit; sph - sfalerit; tt - tetraedrit; q-křemen; carb - karbonát. Foto J. Štelcl.

Abb. 15. Mikrofotografie des Roherzes, Elektronenmikroskop, BSE. py - Pyrit; sph - Sphalerit; tt - Tetraedrit; q Quarz; carb - Karbonat. Foto J. Štelcl. i v automorfních krychlových krystalech několik milimetrů velkých. Méně je zastoupen galenit, nejčastěji v podobě jemnozrnných agregátů velikosti do $1 \mathrm{~cm}$ nebo jako vtroušená zrna rozměrů do $2 \mathrm{~mm} v$ jiných sulfidech. Běžným jevem podél okrajů zrn a na trhlinách je přeměna galenitu na cerusit. Častý je arsenopyrit, jehož agregáty jsou jemnozrnné, jen výjimečně byl makroskopicky zjištěn i v podobě typických kosočtverečných krystalů (obr. 14 a 15, tab. 2).

Mikroskopicky byl zjištěn chalkopyrit, který tvoří bud' inkluze ve sfaleritu, nebo vzácně vystupuje i ve značně přeměněných zrnech. Všechny dále uvedené fáze byly zjištěny pouze jako mikroskopické inkluze $\mathrm{v}$ jiných sulfidech a determinovány na základě výsledků EDX a WD analýz. V galenitu a méně pak v pyritu a sfaleritu jsou časté inkluze tetraedritu o velikosti desítek mikronů (obr. 15), popř́ípadě protažené až žilkovité agregáty tohoto minerálu (obsahuje od 15 do 22 hmot.\% Ag). Dále byly potvrzeny argentit $\left(\mathrm{Ag}_{2} \mathrm{~S}\right)$, pyrargyrit $\left(\mathrm{Ag}_{3} \mathrm{SbS}_{3}\right)$, diaforit $\left(\mathrm{Ag}_{3} \mathrm{~Pb}_{2} \mathrm{Sb}_{3} \mathrm{~S}_{8}\right)$, freislebenit $\left(\mathrm{AgPbSbS}_{3}\right)$ a pravděpodobný zoubekit $\left(\mathrm{Pb}_{4} \mathrm{AgSb}_{4} \mathrm{~S}_{10}\right)$.

Zajímavé jsou koeficienty korelace mezi prvky v rudnině (tab. 2), třebaže je k výsledkům pro malé množství vzorků nutno přistupovat kriticky. Je zjevné, že As, jehož nositelem je arsenopyrit, vystupuje v rudnině nezávisle na ostatních prvcích (nerostech). Koeficient korelace mezi As a Zn je výrazně negativní $(-0,83)$. Za společně vystupující lze považovat $\mathrm{Ag}$-Sb s koeficienty korelace ve vysokých kladných hodnotách $(0,93), \mathrm{Cu}-\mathrm{Sb}(0,93), \mathrm{Cu}-\mathrm{Ag}(0,76)$ a $\mathrm{Zn}-\mathrm{Cd}(0,94)$.

\begin{tabular}{|c|r|r|r|r|r|r|r|r|}
\hline ore sample & $\mathrm{Ag}(\mathrm{ppm})$ & $\mathrm{Pb}(\mathrm{hmot} . \%)$ & $\mathrm{Zn}(\mathrm{hmot} \%)$ & $\mathrm{Cu}(\mathrm{ppm})$ & $\mathrm{Sb}(\mathrm{ppm})$ & $\mathrm{Cd}(\mathrm{ppm})$ & $\mathrm{As}(\mathrm{ppm})$ & $\mathrm{Sn}(\mathrm{ppm})$ \\
\hline KOJ1 & 479 & 1,66 & 16,46 & 825 & 429 & 2492 & 255 & 2 \\
\hline KOJ2 & 644 & 14,47 & 1,36 & 434 & 375 & 136 & 7081 & 2 \\
\hline KOJ4 & 22 & 1,27 & 12,56 & 78 & 64 & 1041 & 32 & 3 \\
\hline KOJ5 & 33 & 3,02 & 3,08 & 157 & 124 & 285 & 9040 & 2 \\
\hline KOJ6 & 304 & 0,26 & 0,65 & 361 & 205 & 66 & 19730 & 3 \\
\hline
\end{tabular}

Tab. 2. Geochemická analýza vzorků rudniny z profilu 1 , hloubky $10-60 \mathrm{~cm}$. KOJ1 - křemenná žilovina se závalky černého sfaleritu do $0,5 \mathrm{~cm}$; KOJ2 - křemenná žilovina s galenitovými zrny do $0,75 \mathrm{~cm}$ velkými, minoritně černý sfalerit; KOJ4 zrna černého sfaleritu v béžovém, jemnozrnném karbonátu; KOJ5 - velmi jemnozrnný sfalerit, méně i pyrit v křemenné žilovině; KOJ6 - křemenná žilovina s krystaly pyritu do $3 \mathrm{~mm}$, jemnozrnným arzenopyritem a podružným černým sfaleritem.

Tab. 2. Geochemische Analyse der Roherzeproben aus Profil 1, Tiefe 10-60 cm. KOJ1 - quarzhaltiges Ganggestein mit bis zu 0,5 cm großen schwarzen Sphaleritklümpchen; KOJ2 - quarzhaltiges Ganggestein mit bis zu 0,75 cm großen Galenitkörnern, minoritär schwarzer Sphalerit; KOJ4 - Körner des schwarzen Sphalerits in feinkörnigem, beigem Karbonat; KOJ5 sehr feinkörniger Sphalerit, geringer auch Pyrit in quarzhaltigem Ganggestein; KOJ6 - quarzhaltiges Ganggestein mit bis zu 3 mm großen Pyritkristallen, feinkörnigem Arsenopyrit und sekundärem schwarzen Sphalerit. 
To plně odpovídá uvedené mineralogické charakteristice rudniny a potvrzuje vazbu $\mathrm{Ag}$ na komplexní sulfidy Ag-Pb-Sb-Cu.

\section{Hmotná kultura}

\subsection{Mlecí kameny}

Nálezovou situaci doplňují úlomky dvou mlecích kamenů z řečiště asi $20 \mathrm{~m}$ od profilu 1 (obr. 16). Jsou přímým indikátorem existence rudního mlýna. Oba zlomky jsou sekány z žuly, u níž je na území s běžným rozšířením těchto hornin prakticky vyloučena možnost lokalizace zdroje. Na povrchu pracovních stran obou žernovi̊ nejsou patrné charakteristické koncentrické rýhy, způsobené rotací při mletí rudniny. U většího $z$ obou kusů je patrná paprsčitá rýha, přičemž však prolákliny na povrchu naznačují, že kámen mohl být po puknutí, či jinak zapříčiněném vyřazení z mlýna používán jako podložka pro ruční roztloukání, poprrípadě jako podklad pod palici stoupy. U menšího z žernovů lze odhadnout jeho původní průměr na $44 \mathrm{~cm}$, u většího pak na $68 \mathrm{~cm}$.

\subsection{Archeometalurgické nálezy: diskovitý olověný slitek}

Do této skupiny patří pouze slitek olova nalezený detektorovým průzkumem. Jedna strana je plochá a druhá konvexně vypouklá, může tedy jít o výlitek dna misky nebo kelímku. Průměr slitku je $4,5 \mathrm{~cm}$, maximální výška $0,9 \mathrm{~cm}$ a hmotnost 102,80 g (obr. 17:2). Na povrchu je pokryt bílou oxidační práškovitou vrstvou tvořenou fází odpovídající cerusitu. Podle XRF analýz i EDX analýz v elektronovém mikroskopu je slitek tvořen čistým a chemicky homogenním olovem $(99,96$ až 98,83 hmot. \% Pb).
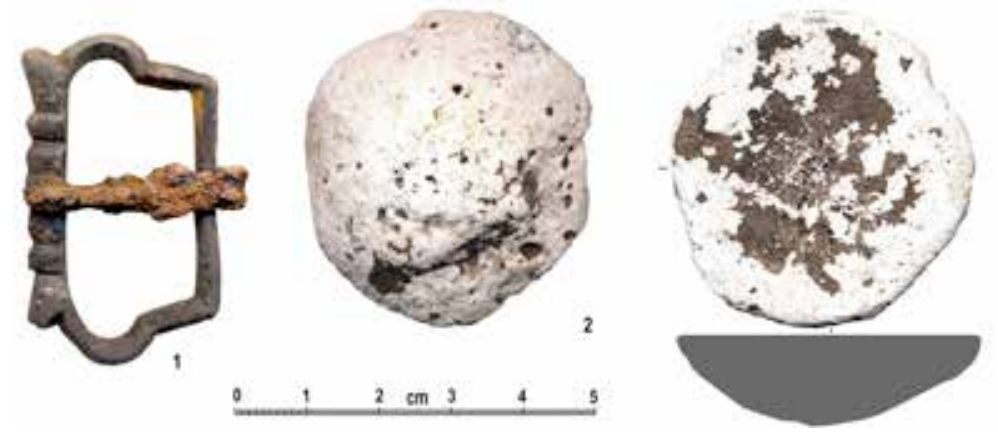

Obr. 17. Opasková přezka a slitek olova, nalezeno detektorovým průzkumem. Foto a úprava P. Hrubý. Abb. 17. Gürtelschnalle und Blei-Ofensau, gefunden durch Metalldetektor. Foto und Bearbeitung P. Hrubý. 

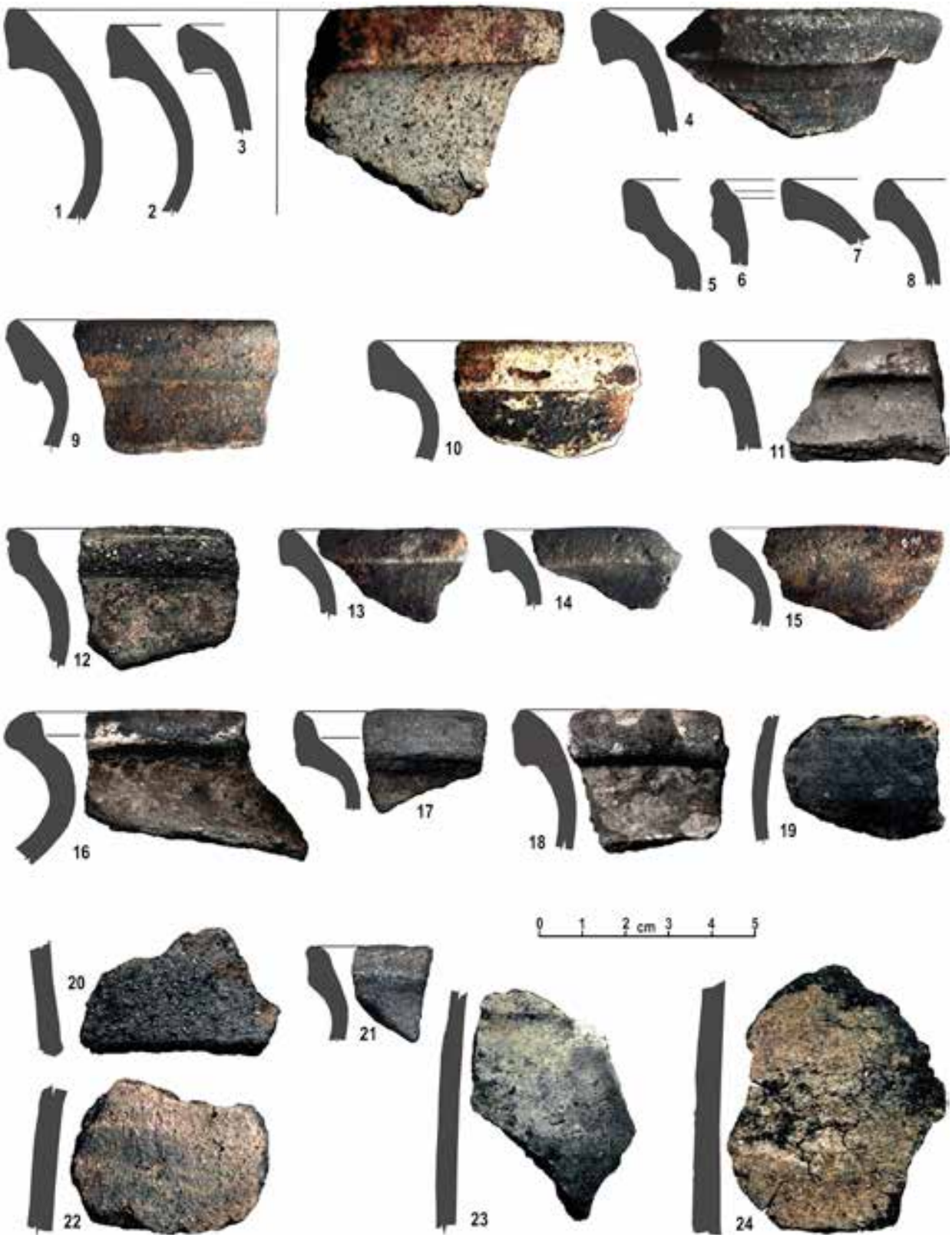

Obr. 18. Keramika z profilu 1. Foto a úprava P. Hrubý.

Abb. 18. Keramik aus Profil 1. Foto und Bearbeitung P. Hrubý. 
Z proměnlivého množství příměsí bylo zjištěno jen $0,04-0,40$ hmot. \% Sn, dále $0,04-0,35$ hmot. \% Sb, dále 0,01-0,04 hmot. \% Cu, pak 0,03-0,10 hmot. \% Fe a do 0,02 hmot. \% Zn.

\subsection{Keramický soubor}

Soubor čítá 171 fragmentů a až na několik exemplářů z celoplošného detektorového průzkumu byl nalezen při exkavaci profilu 1. Kvalita souboru je nízká. Velikostí fragmentů, malým podílem určitelných exemplářủ a zachovalostí se soubor podobá spíše sběrovému materiálu. Fragmenty jsou až na výjimky menší (délka $5-6 \mathrm{~cm}$ ). Keramika převažuje v uloženinách $0102-$ 0103 (obr. 6-8), zatímco ve vrstvách tvořených jemně mletým a nejspíš i plaveným materiálem je jí výrazně méně. Keramické nálezy téměř úplně absentují v plastických technogenních uloženinách, jejichž vznik je spojen s vodní sedimentací.

Charakteristickým znakem keramiky z deponie rudniny je naleptání povrchu střepů (obr. 18:1, 20, 24; obr. 19:5, 8). Příčinou je velmi kyselé prostředí ve zvětrávající rudnině s $\mathrm{pH}$ až 2-3 a korozívní působení síranových iontů (zejména $\mathrm{SO}_{4}{ }^{2-}$ ). $\mathrm{V}$ mnoha případech byl na povrchu střepů tenký, celoplošně a vesměs rovnoměrně rozložený povlak hnědavě rezavého zbarvení. V několika př́padech byla na povrchu střepů zaznamenána tmavě hnědavá krusta. Tyto povlaky jsou tvořeny vysráženými hydroxidy, sírany, uhličitany a př́ípadně i fosfáty Fe a Mn, tedy prvků v rudnině.

Materiálově lze rozlišit 29 fragmentů tuhové keramiky (17\% souboru), přičemž grafit byl prrítomen převážně $\mathrm{v}$ podobě drcených či mletých rozeznatelných zrnek. Jen necelá desítka fragmentů byla z jemné hlíny a s hladce zpracovaným povrchem. Čtyři fragmenty lze označit jako světlou šedou až béžovou keramiku, třebaže šlo o standardní hrnčinu.

Většina přiřaditelných fragmentů patří bezuchým hrncům, popř́ípadě mísám (obr. 18:1-18, 21). Této skupině lze přiřadit většinu okrajů (Procházka-Peška 2007, 248-252, 258). K hrncům patří nejspíš i výdutě, charakteristické absencí výzdoby (obr. 18:20, 22-24; obr. 19:1-5, 14). Výjimkami jsou fragmenty s vodorovnou linkou, případně s jemnou šroubovicí (obr. 19:3, 14). Dna, rovněž přiřaditelná hrncům, mají stopy podsýpky, odříznutí se nevyskytuje a nalezeny nebyly ani značky (obr. 19:8, 15, 16). S hrnci nejspíš souvisí i početné zastoupení pokliček, jejichž profilace dovoluje hovořit o kónických, popřípadě zvonovitých nebo i miskovitých typech (obr. 19:9-13). Charakteristická je absence zásobnic. V souboru rovněž nebyla nalezena metalurgická keramika, jako např́ílad střepy s nataveninami, testovací či kupelační misky, kelímky a tyglíky.

Svými znaky odpovídá keramika obecně 13.-14. století. Vzhledem k sérii dendrochronologických dat z krátké časové sekvence 1253-1258 (tab. 1) není keramika řídícím chronologickým ukazatelem. Naopak, chronologie se $\mathrm{v}$ tomto př́ípadě ŕídí dendrodaty ze zkoumané situace, a nalezenou keramiku tak podle toho můžeme klást do doby krátce po polovině 13. století. Navzdory přesnému datování aktivit v úpravnickém areálu však keramický soubor kvůli své nízké kvalitě a zjevné netypičnosti může jen stěží posloužit jako bezpečné chronologické vodítko při klasifikaci středověké keramiky v regionu.

\subsection{Organické a archeozoologické nálezy}

Ve čtverci 1 byly při exkavaci profilu 1 nalezeny kožené odřezky i dva dílce se švy, snad z obuvi (obr. 20:2,3). Tato skupina artefaktů patř́i ve středověkých zpracovatelských areálech k běžným nálezům (Hrubý a kol. 2012, 397-399; Crkal 2018, 180, obr. 101). Výjimečným nálezem je útržek vlněné textilie s plátnovou vazbou, pocházející rovněž z anaerobního prostředí antropogenních plastických uloženin nad holocenní bázi v hloubkách 110-130 cm (obr. 21). Při odebírání vzorků z uloženiny 0106 byly zachyceny zvířecí chlupy (obr. 22) a také peří. Analýzou pod biologickým mikroskopem Nikon H550S při zvětšení $50 \times 24$ bylo zjištěno, že jde o srst z těla koně (Nývltová Fišáková 2018). 

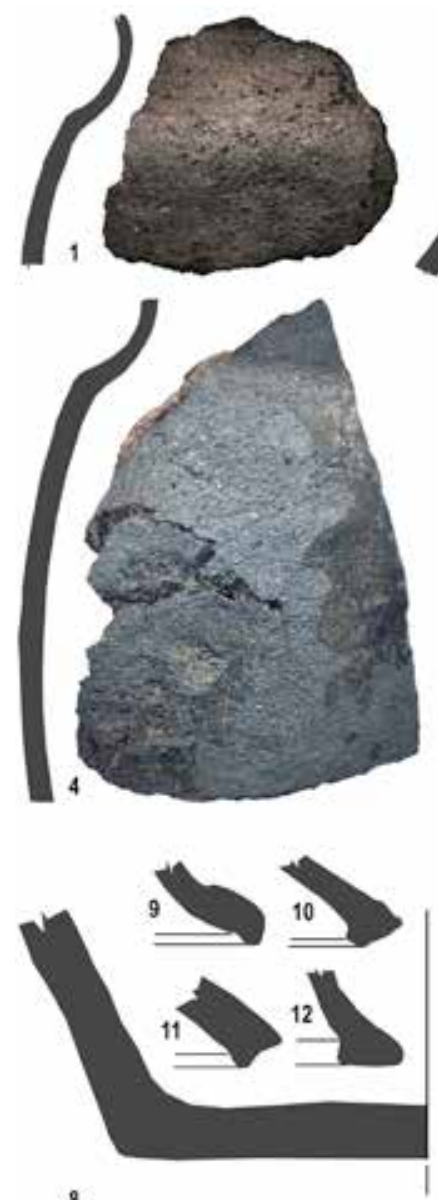

8

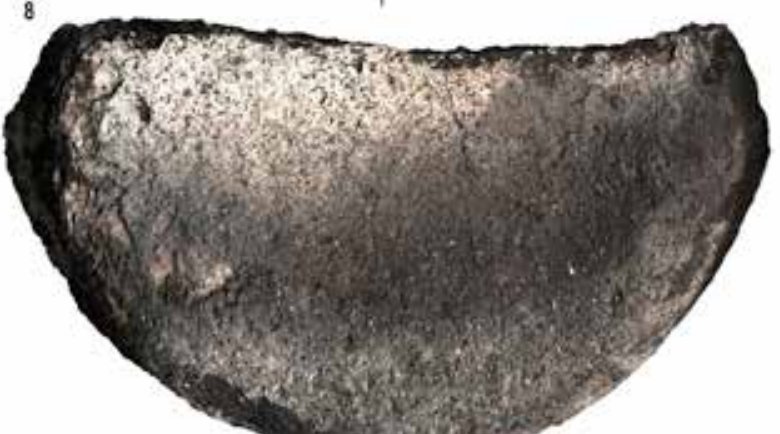

$0 \quad 2 \quad \mathrm{~cm}^{3} \quad 4 \quad 5$

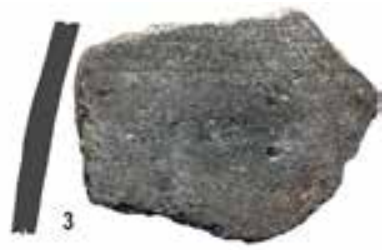

2
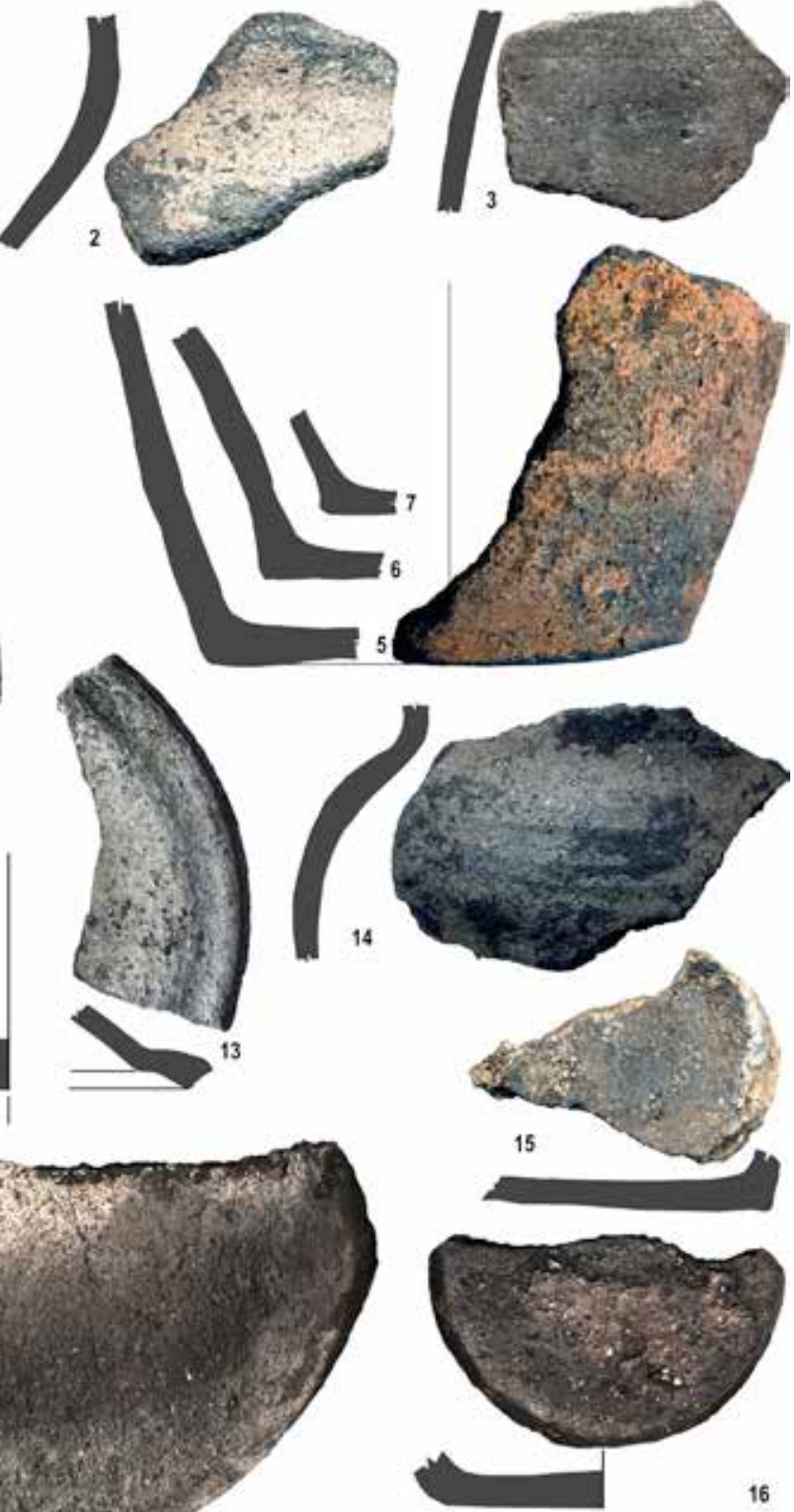

16

Obr. 19. Keramika z profilu 1. Foto a úprava P. Hrubý.

Abb. 19. Keramik aus Profil 1. Foto und Bearbeitung P. Hrubý. 


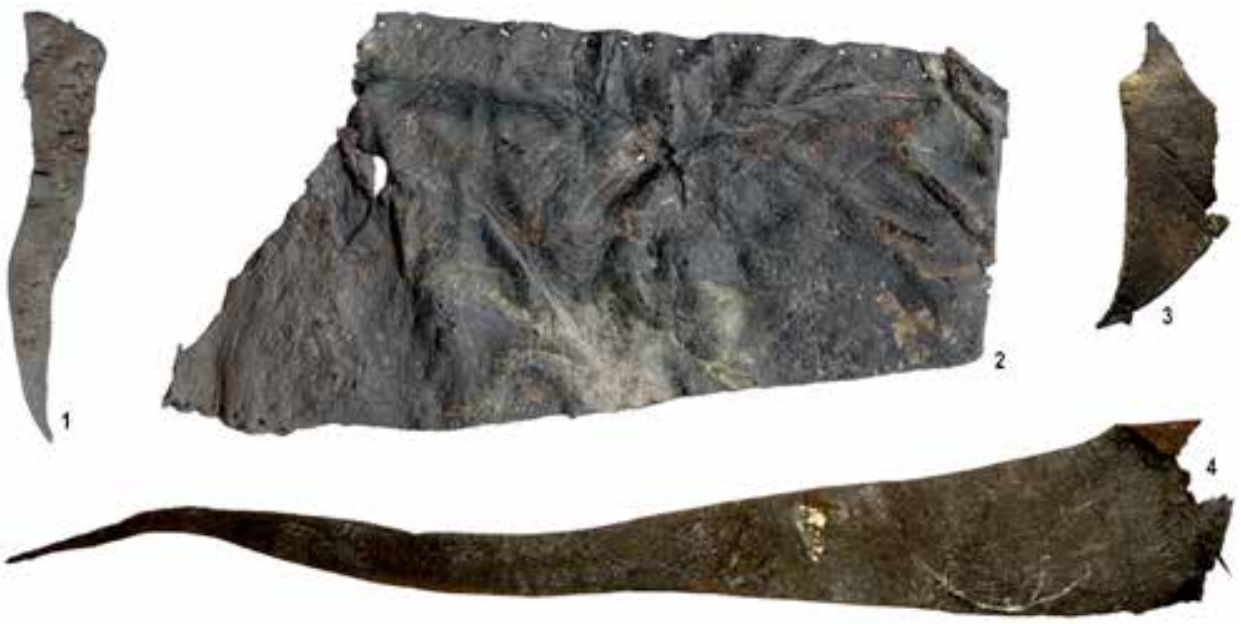

Obr. 20. Části kožené obuvi nebo oděvu, odřezky a nespecifikovaný dílec se švy. Foto P. Hrubý.

Abb. 20. Bestandteile von Lederschuhwerk oder Bekleidung, Lederschnipsel und nicht spezifiziertes Lederstück mit Naht. Foto P. Hrubý.
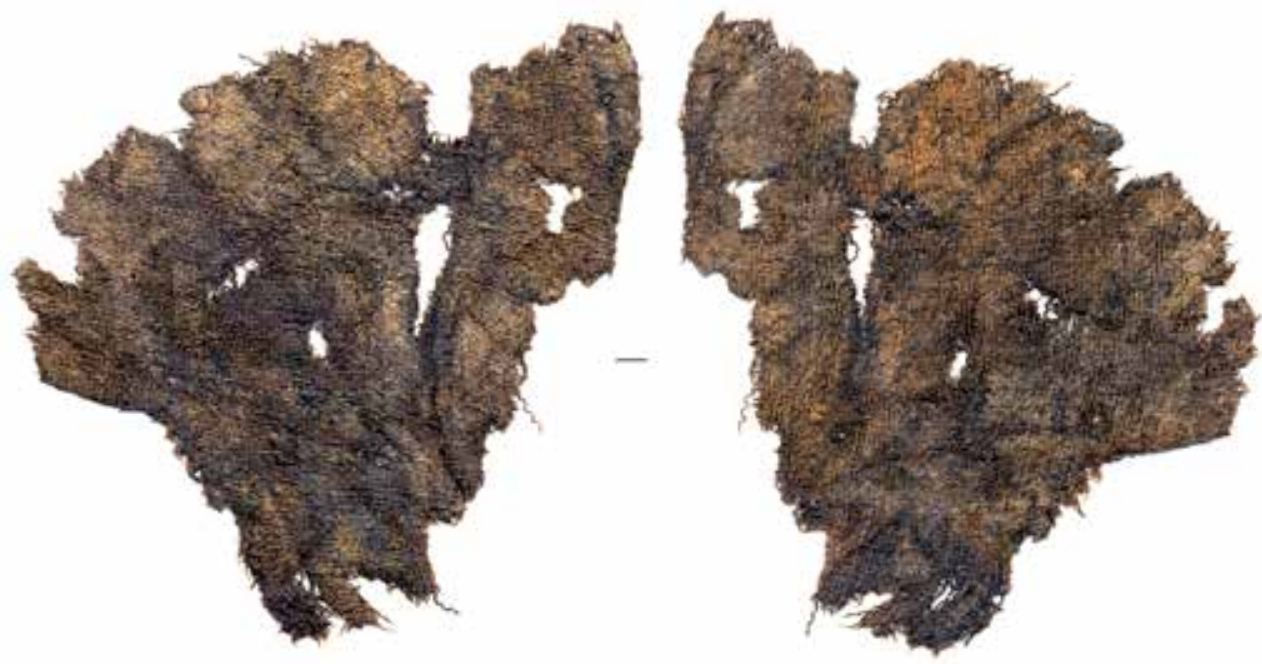

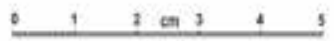

Obr. 21. Útržek vlněné textilie s plátnovou vazbou. Foto $P$. Hrubý.

Abb. 21. Leinentextilstreifen in Leinenbindung. Foto P. Hrubý. 

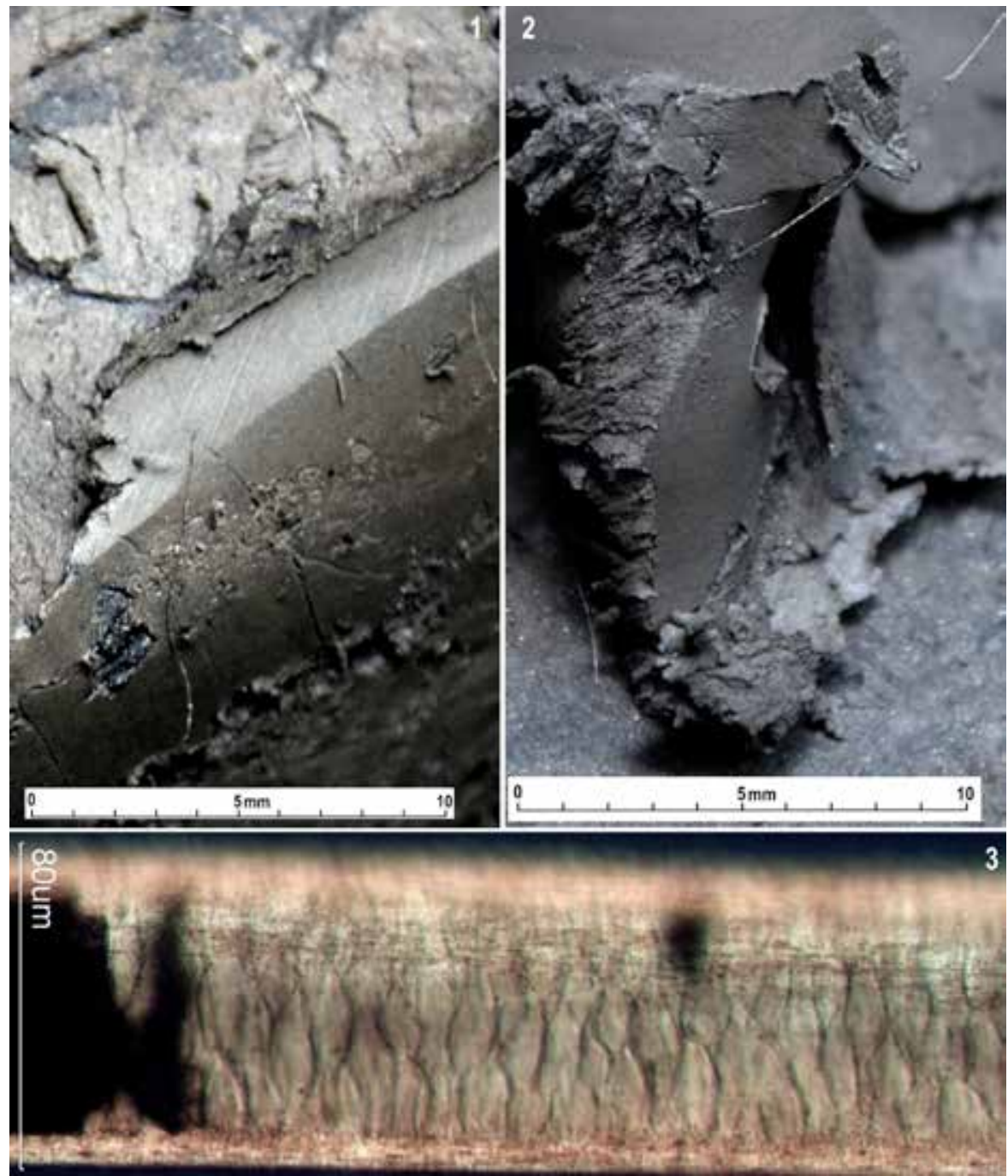

Obr. 22. Koňská srst z uloženiny 0106. 1-2 - foto J. Mazáčková; 3 - foto z mikroskopu podle Nývltová Fišáková, 2018. Abb. 22. Pferdehaare aus Ablagerung 0106. 1-2 - Foto J. Mazáčková; 3 - Mikroskopbild nach Nývltová Fišáková, 2018.

\subsection{Kovové artefakty}

V dosud zkoumaných stratigrafiích profilu 1 nebyl nalezen žádný kovový předmět, všechny pochází z detektorového průzkumu v okolí (obr. 23). Důlní činnost ilustrují dvě hornická želízka, jedno dochované jen fragmentárně (obr. 24). Rozšířenými artefakty jsou koňské podkovy, kterých bylo nalezeno 18 kusů (obr. 25). Nejvíce jsou zastoupeny typy 5a-c, dále $6 \mathrm{~d}$ a ojediněle 4c či 6c (Krajíc 2003, 103). Jezdeckou složku zastupují tři udidla a hvězdice z ostruhy. Nalezena byla také ostruha s prohnutými rameny s manžetou a krátkou rovnou vidlicí. Očka jsou zdvojená (obr. 26:5). Tento typ byl používán ve 14. až 15. století, což se archeologickým situacím v profilu 1 i dendrodatu z profilu 2 vymyká. 


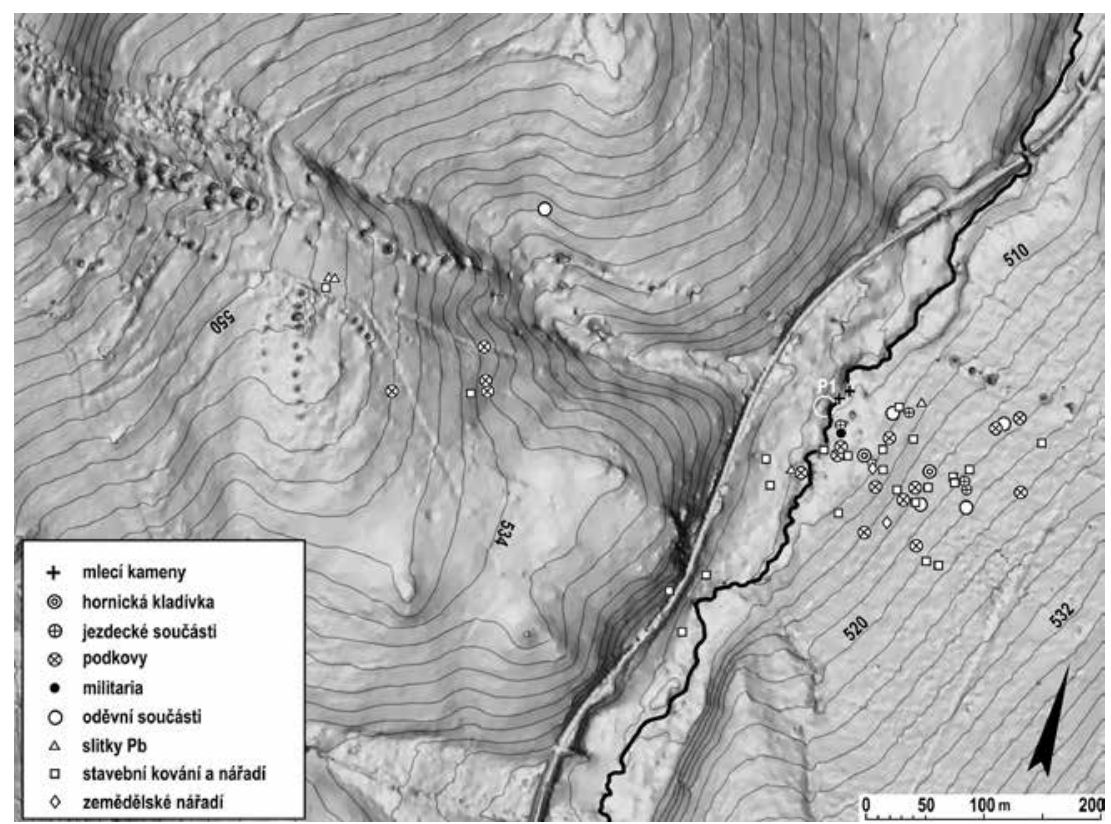

Obr. 23. Prostorová distribuce kovových artefaktů podle detektorové prospekce. Podkladová reliéfní mapa LiDAR 5G (ALS).

Abb. 23. Räumliche Verteilung der Metallartefakte entsprechend der Metalldetektorsuche. Unterlage Reliefkarte LiDAR 5G (ALS).
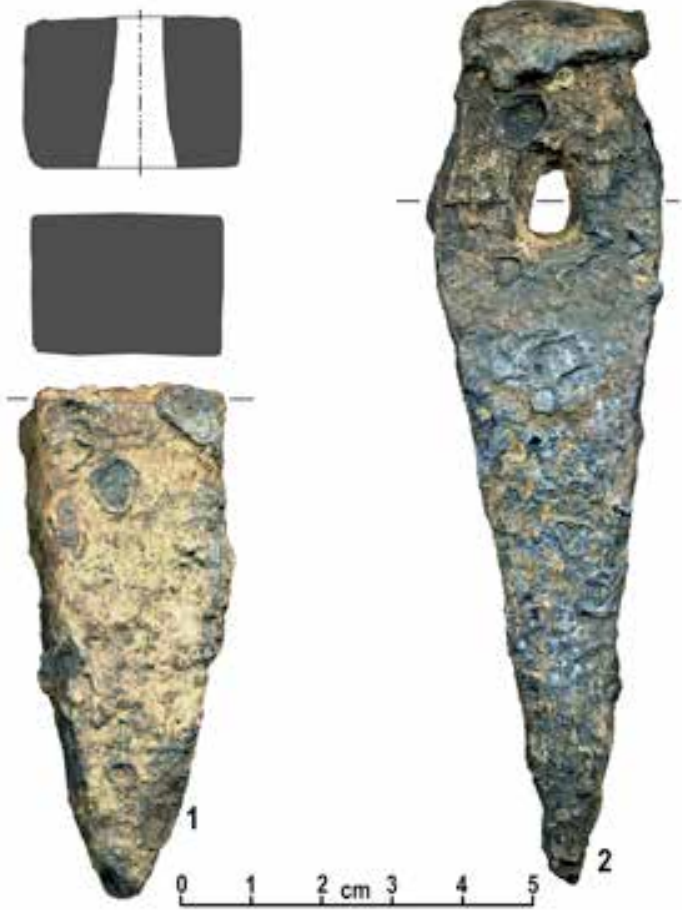

Obr. 24. Hornická kladívka z prospekce detektorem kovů (srov. obr. 23). Foto J. Těsnohlídek, úprava P. Hrubý. Abb. 24. Bergeisen von der Metalldetektorsuche (vgl. Abb. 23). Foto J. Těsnohlídek, bearbeitet von P. Hrubý. 

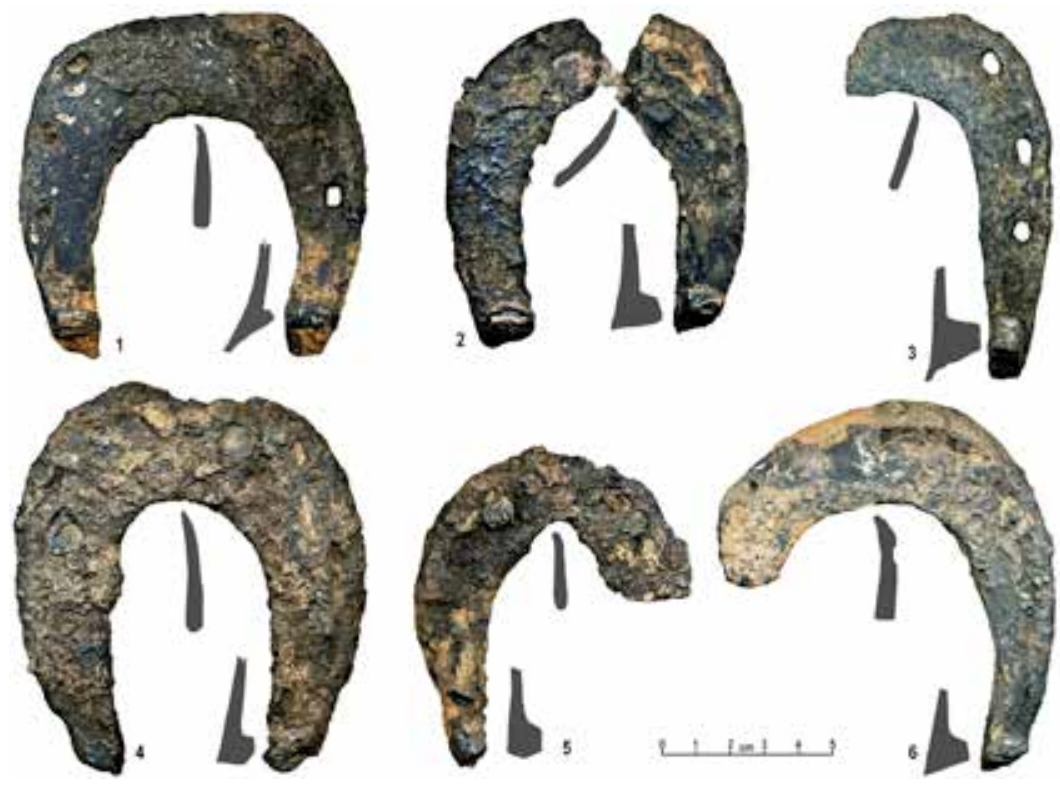

Obr. 25. Podkovy z prospekce detektorem kovů (srov. obr. 23). Foto J. Těsnohlídek, úprava P. Hrubý.

Abb. 25. Hufeisen von der Metalldetektorsuche (vgl. Abb. 23). Foto J. Těsnohlídek, bearbeitet von P. Hrubý.

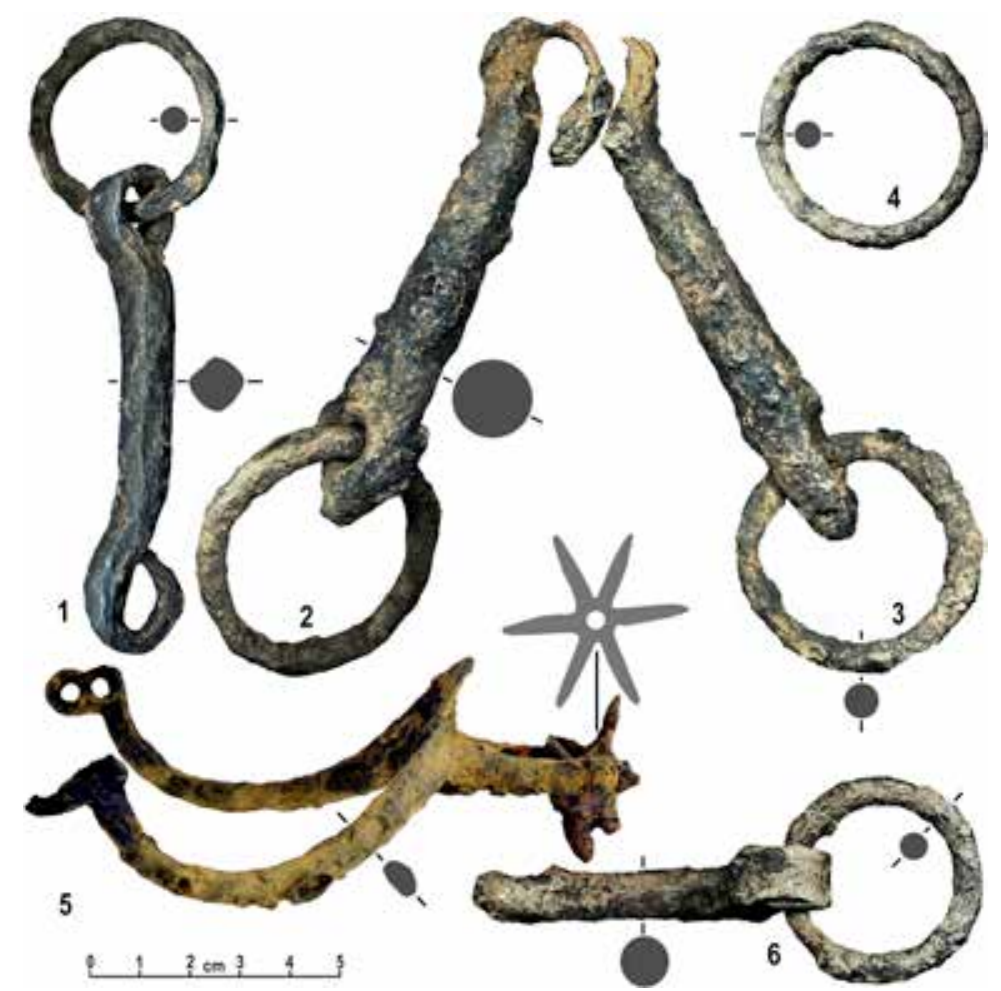

Obr. 26. Železné artefakty z prospekce detektorem kovů (srov. s obr. 23). Foto J. Těsnohlídek, úprava P. Hrubý. Abb. 26. Eisenartefakte von der Metalldetektorsuche (vgl. Abb. 23). Foto J. Těsnohlídek, bearbeitet von P. Hrubý. 


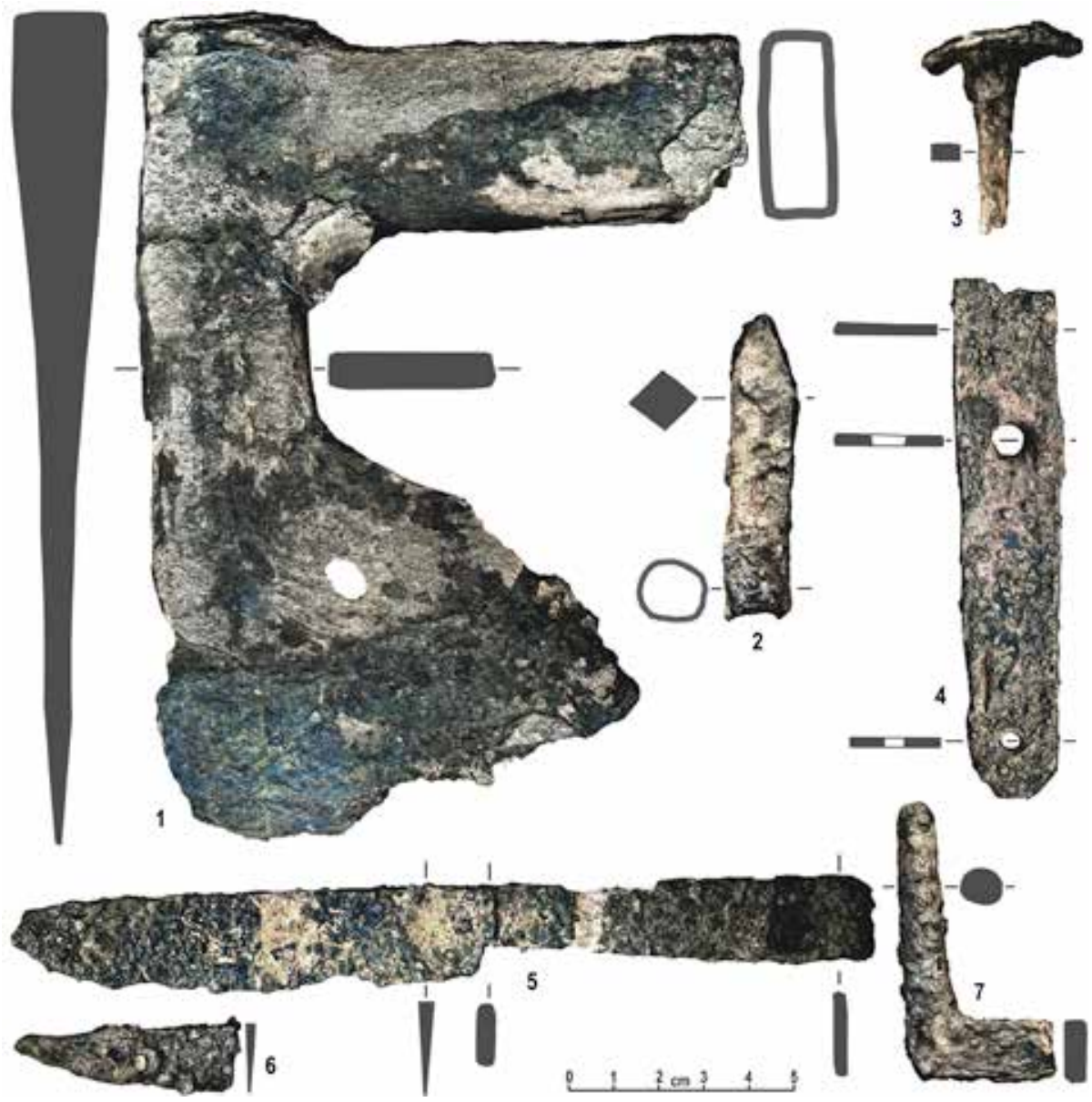

Obr. 27. Železné artefakty z prospekce detektorem kovů (srov. obr. 23). Foto J. Těsnohlídek, úprava P. Hrubý. Abb. 27. Eisenartefakte von der Metalldetektorsuche (vgl. Abb. 23). Foto J. Těsnohlídek, bearbeitet von P. Hrubý.

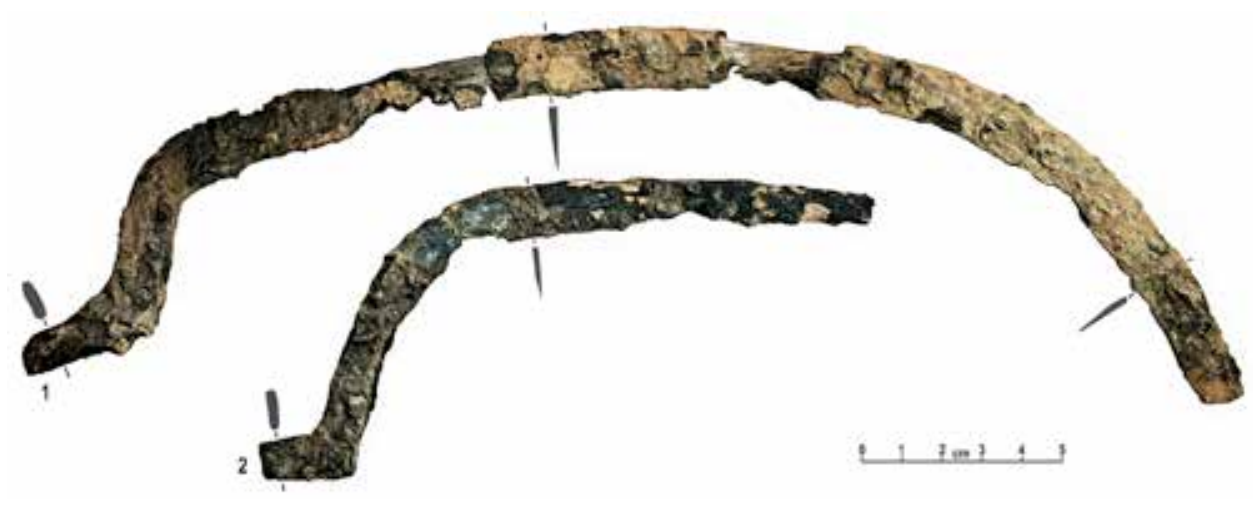

Obr. 28. Srpy z prospekce detektorem kovů (srov. obr. 23). Foto J. Těsnohlídek, úprava P. Hrubý.

Abb. 28. Sicheln von der Metalldetektorsuche (vgl. Abb. 23). Foto J. Těsnohlídek, bearbeitet von P. Hrubý. 
$\mathrm{K}$ řemeslným nástrojům řadíme drobné tesařské kladivo s hřebem $\mathrm{v}$ otvoru pro rukojet', klín a sekyru (obr. 27:1). Jednobřitý kovaný nůž s řapem a tenkými bolstry lze díky subtilnějším rozměrům zařadit spíše k výbavě domácnosti (obr. 27:5).

Stavební kování je zastoupeno hřeby, pásovinou s otvory a háky pro zavěšení dveří (obr. 27:3, 4, 7). Z výstrojních a oděvních součástí lze jmenovat mosaznou opaskovou přezku (obr. 17:1). Do souboru patř́i i další dva trny z přezek. Militaria jsou zastoupena šipkou do kuše s tulejkou (obr. 27:2). K zajímavým nálezům patří dva exempláře srpů. Ty jsou v hornickém prostředí jednoznačně neobvyklé (Derner-Hrubý 2018, 223, obr. 17). Mohou být dokladem př́ležitostného zemědělství zdejší středověké hornické komunity, ovšem stejně tak nemusí s důlními areály vůbec souviset.

\section{Diskuse, závěry a hypotézy}

\subsection{Proměna středověké krajiny v důsledku hornické činnosti}

Zaměříme-li se na nejstarší stopy lidské činnosti dokumentované na profilu 1, uvidíme příznačně mýcení středověkého lesa. V tomto př́ípadě jej však nepodnítila zemědělská kolonizace, nýbrž prospektorská a důlní činnost, jejíž počátky lze tušit možná už v roce 1253. Podle analýzy uhlíků i nezuhelnatělých makrozbytků z uloženin mezi smýcenými kmeny odpovídá středověká skladba lesa v údolí potoka klimaxovému společenstvu kyselé až květnaté jedliny a jedlobučiny. Přímo na březích se nalézala azonální potoční olšina (Kočár-Kočárová 2017). Mezi ležícími kmeny však ve všech profilech převládá jedle, což dokládá selektivní mýcení, popřípadě stahování dřeva k potoku. Opálení některých dřev může souviset s vypalováním, kterým bylo mýcení obvykle doprovázeno.

Na dokumentované situaci zaujme především zacházení s hodnotným stavebním dřevem, které zůstalo ležet na místě a bylo při provozu úpravny postupně překryto úpravnickým odpadem. Tato masa možná měla zpevnit a zvýšit terén kvůli hladině vody. Pouze na nejsevernějším profilu 3 po proudu Nohavického potoka lze u mohutného jedlového kmene (prvek 0453), řezaného ze spodní strany pilou a z horní strany odtesaného sekyrou, pozorovat plošně odštípnutí, tedy z geometrického hlediska po tětivě (obr. 29). Na základě analogií z prádel na lokalitě Cvilinek na Pelhřimovsku se lze domnívat, že jde o doklad standardního a technicky dobře zvládnutého štípání desek (Hrubý a kol. 2012, 361).

\subsection{Interpretace archeologické situace v profilu 1}

Při exkavaci byly odkryty relikty dřevěné konstrukce převrstvené rudninou. Př́imé analogické struktury jsou známy ze soudobé lokality Cvilinek na Pelhřimovsku (Hrubý a kol. 2012, 352). Další komponentou je namletá, prrípadně i propíraná rudnina. To spolu s fragmenty mlecích kamenů dovoluje uvažovat o pozůstatcích úpravny, v níž mohla pracovat stoupa (obr. 30) a jejíž součástí byl také rudní mlýn. Podle nálezů mlecích kamenů v řečišti je možné uvažovat o pohonu vodním kolem, nelze však říci, zda spodem, nebo horem. Součástí pracoviště byla nejspíš i prádla. Nálezy koňské srsti v provozních vrstvách odpovídají představě transportu rudniny od důlních jam koňskými povozy (obr. 33).

Úpravna byla podle dendrodat zřízena nejpozději po roce 1258, což je datum, k němuž lze vztáhnout i zahájení zdejší důlní činnosti. Nejasná je doba opuštění stanoviště, o čemž ani dendrodata, ani keramické nálezy nevypovídají. Nálezová situace působí dojmem rychle zřízeného krátkodobého pracoviště. Vzájemné vztahy mezi technogenními sedimenty a konstrukčními dřevy naznačují, že pracoviště bylo brzy zaneseno vlastním provozním odpadem, což je obvyklý jev (Hrubý a kol. 2012, 358). Krátkodobá chronologie profilu 1 však nevypovídá o celkové délce života zdejších dolů a úpraven, spíše je nutno předpokládat, že pracoviště se podle potřeby po čase přesouvala a profil 1 zachytil nejstarší fázi jednoho z nich. 


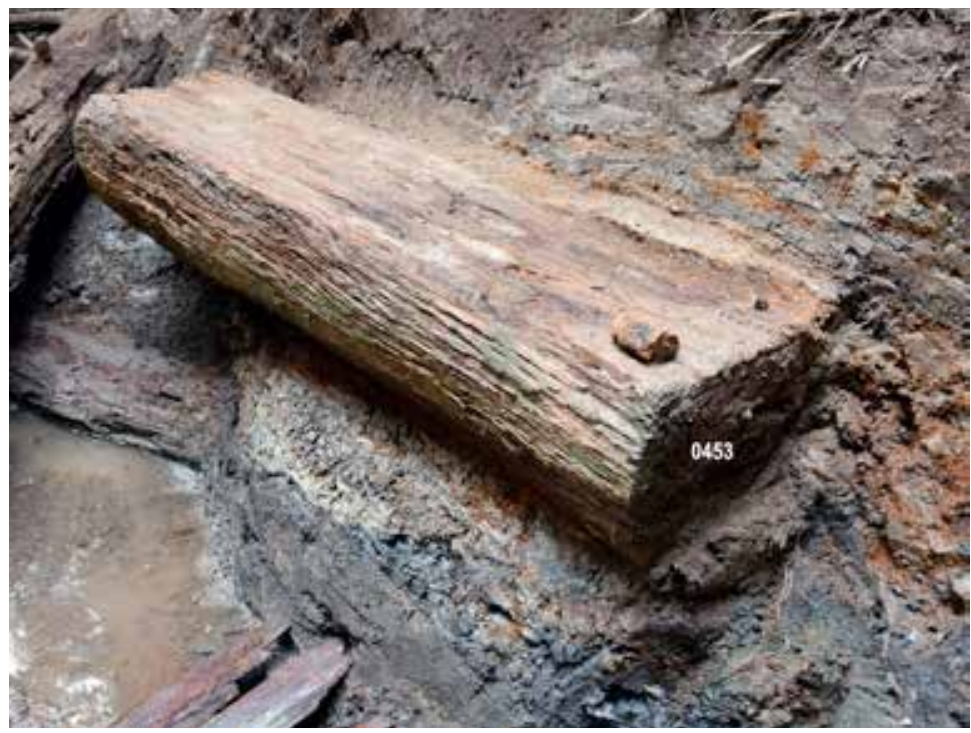

Obr. 29. Profil 3 a štípané jedlové dřevo 0453. Foto P. Hrubý.

Abb. 29. Profil 3 und gespaltenes Tannenholz 0453. Foto P. Hrubý.

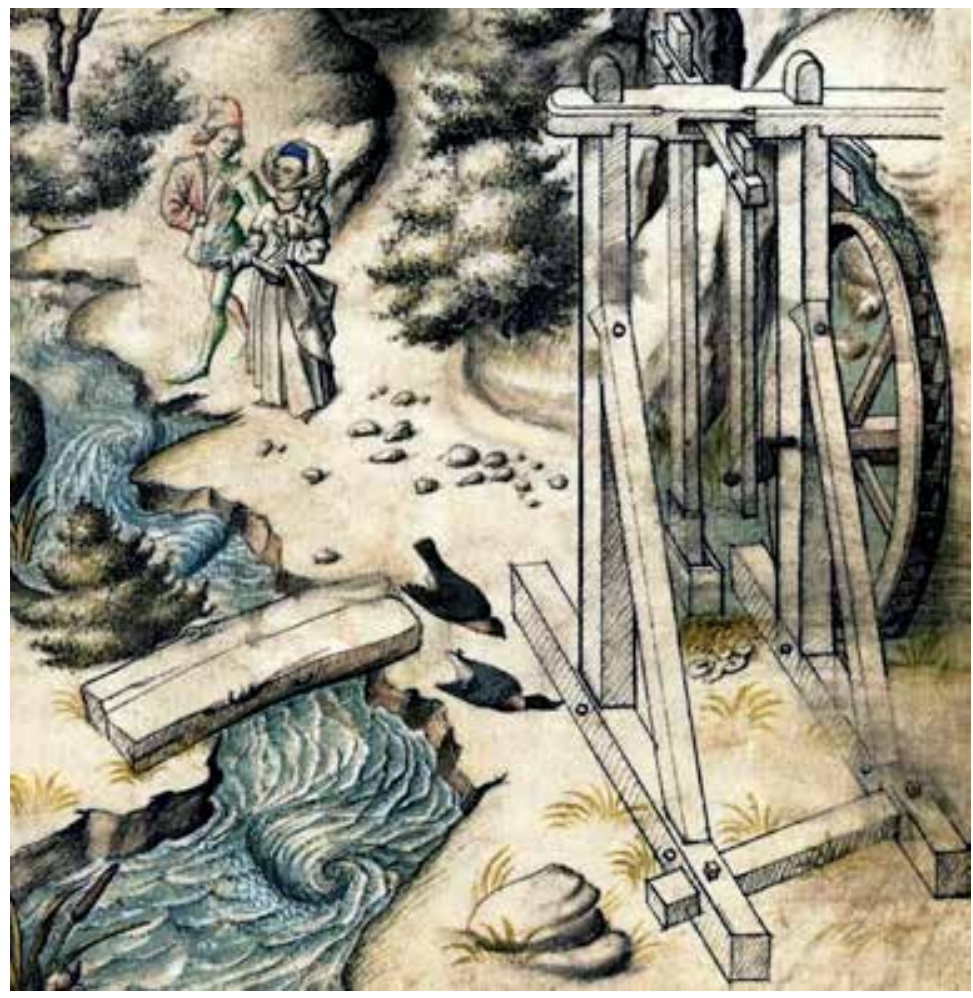

Obr. 30. Jednopalicová stoupa poháněná vodním kolem, Das mittelalterliche Hausbuch von Schloss Wolfegg, někdy po roce 1480 .

Abb. 30. Von einem Wasserrad angetriebenes Pochwerk mit einem Pochstempel, Das mittelalterliche Hausbuch von Schloss Wolfegg, irgendwan nach 1480. 
Analogii integrované úpravny polymetalických rud poskytuje lokalita Brandes en Oisans ve francouzských Alpách. Zde bylo nalezeno značné množství mlecích kamenů a pozůstatky rudního mlýna tvořené kvadratickou komorou z kamenného zdiva a výdřevy s dendrodatem 1210/1211. Ve výplních přilehlých nádrží jsou pravidelně nalézány drobné odštěpky mlecích kamenů, což dokládá technologické i prostorové propojení prádel a mlýna (Bailly-Maître-Minvielle Larousse 2011a, 468, Fig. 9 a 10; 2011b; Minvielle Larousse 2017).

Jak mohl rudní mlýn ve 13. století - alespoň přibližně - vypadat? Konstrukce může být shodná s tím, co známe z vyobrazení 16. století, byla však asi subtilnější (obr. 31 a 32). Spíše než z hranolů byl mlýn sestaven z kuláčů, podle potřeby přitesaných. Srdcem mlýna byly dva mlecí kameny, běhoun a ležák. Běhoun, umístěný nahoře, byl masivnější nežli ležák, aby vlastní vahou přispíval k rozemílání a př́liš nenadskakoval. Nadrcená rudnina se do oka běhounu vpravovala násypným košem, jehož podobu neznáme. Mlecí plochy kamenů byly vyspádovány do kužele, aby rozemílaná rudnina postupovala od středu k okrajům. Na rozdíl od 16. století nemají starší mlýny ležák s luby, takže mletá rudnina volně padala nebo stékala po celém obvodu. Je proto možné, že tzv. hranice byla překryta plošinou a luby. Běhoun byl opatřen tzv. kypřicí, což je dřevěná zarážka, která zapadla do vytesaných křídlovitých prohlubní při středovém otvoru a přenášela tak otáčení ze soukolí a z osy na kámen. Rudní mlýn (obr. 31:1) poháněný vertikálním vodním kolem se předpokládá na lokalitě Teufelsgrund ve Schwarzwaldu (Straßburger 2014, Taf. 277:3-4). V otázkách konstrukce a rozměrů kola je nutno spolehnout se na výzkumy obilných mlýnů (Galusová 2015, 280-281, 286, obr. 14).

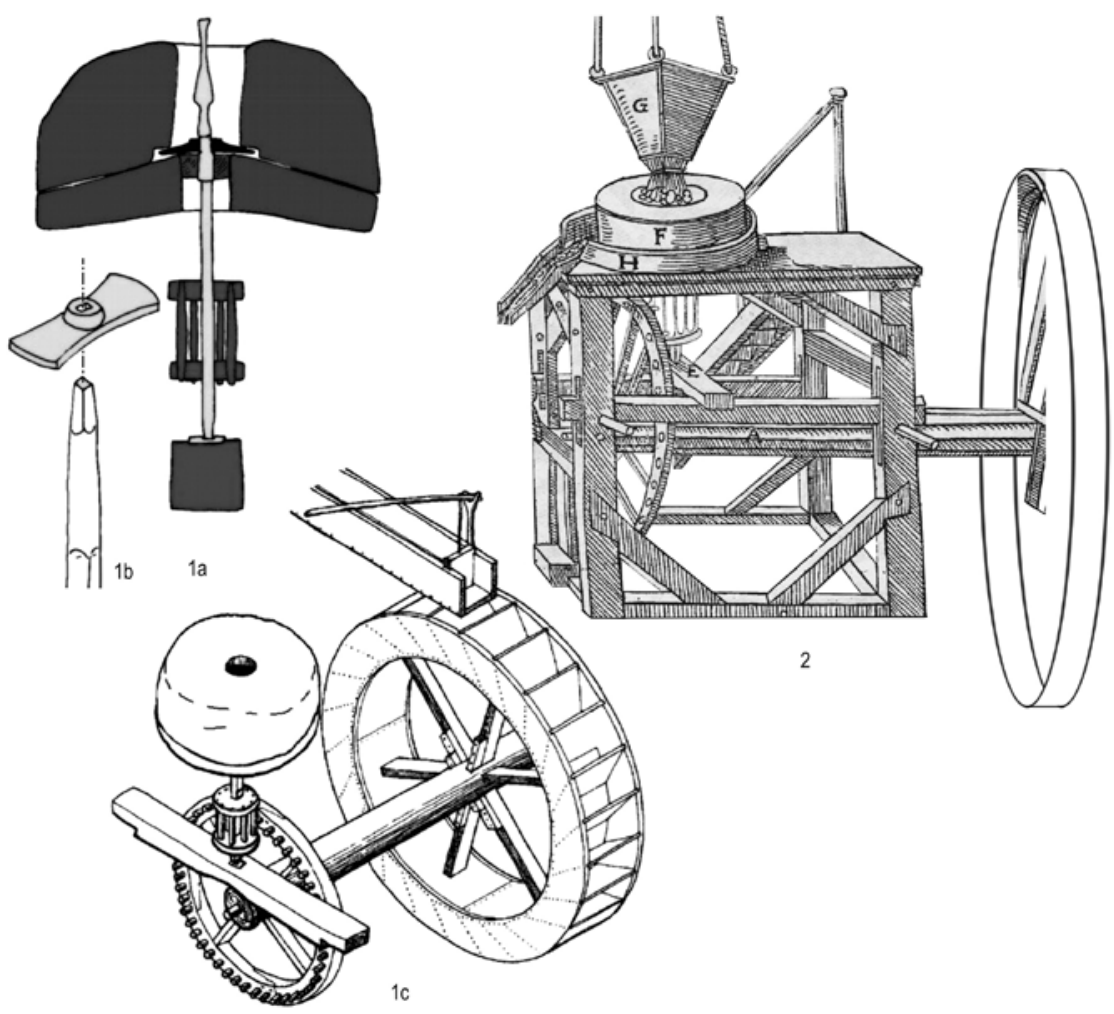

Obr. 31. Rudní mlýny ve středověku a raném novověku. 1 - Rekonstrukce na základě nálezů z lokality Teufelsgrund v jižním Schwarzwaldu. Podle Straßburger 2014, Taf: 277:3-4; 2 - Rudní mlýn podle G. Agricoly v polovině 16. století. Podle Ježek-Hummel 2001.

Abb. 31. Erzmühlen im Mittelalter und in der frühen Neuzeit. 1 - Rekonstruktion anhand von Funden von der Fundstelle Teufelsgrund im Südschwarzwald. Nach Straßburger 2014, Taf: 277:3-4; 2 - Erzmühle nach G. Agricola in der Mitte des 16. Jahrhunderts. Nach Ježek-Hummel 2001. 
Závěrečná etapa výzkumu u Koječína bude zaměřena na př́ípadné provozní odštěpky žernovů, ale i na separaci menších dřev, v nichž mohou být rozpoznány stavební a spojovací součástky mlýna (např. lopatky, kolíky z cévníku či palečnicového kola), ale i užitkové předměty (Crkal 2018, 181, obr. 102). Při vyhodnocení konstrukčních dřev z Koječína bude kromě uvedených analogií přihlédnuto především $\mathrm{k}$ dodnes ojedinělým výsledkům výzkumu středověké zlatorudné úpravny a zlatomlýna v Písku „Pod starou pazdernou“ (Kudrnáč 1988, 6-11, tab. 25-76, 119 a 193, Plány 5-8).

\subsection{Složení rudniny a otázka cílových rud- ních koncentrátů vyrobených v úpravně}

Hlavní těženou rudou $\mathrm{v}$ širším slova smyslu byl galenit, a to jako zdroj všestranně potřebného olova i jako koncentrátor stříbra, které však bylo vázáno v samostatných minerálech. Dnes se můžeme jen dohadovat, zda stř́brné rudy byly v době vyvrcholení středověké těžby pouze mikroskopické (popřípadě submakroskopické), nebo zda měly i podobu agregátů. $\mathrm{V}$ druhém př́ípadě by $\mathrm{k}$ jejich separaci dostačovalo ruční roztloukání a třídění. Doložené mletí rudniny na jemnou frakci však spíše odkazuje na snahu o pečlivou a co nejméně ztrátovou gravitační separaci galenitu a na něj vázaných inkluzí minerálů stříbra. Vzhledem k milimetrové frakci sedimentu lze uvažovat o vícefázovém mletí podle požadavku na velikost zrna.

Obtížně řešitelná je otázka kovnatosti rud těžených zde ve středověku. Analyzované vzorky pochází v každém případě z upravené rudniny. Může jít o sklad vytříděné kvalitní rudniny, která měla být dále zpracována, $\mathrm{k}$ čemuž však z neznámých důvodů již nikdy nedošlo. Na druhé straně mohou deponie reprezentovat prvotně upravenou, ale nepotřebnou rudninu nízké kvality, z níž již byla hodnotnější složka vytř́íděna. Kovnatosti v jednotkách až desítkách hmot. \% pro $\mathrm{Pb}$ a prvních stovkách ppm pro Ag lze u vytř́iděné polymetalické rudniny z ložisek Českomoravské vrchoviny nejspíš považovat za standard (tab. 2).

Pokud jde o zjištování obsahu cínu v rudnině, jedním z důvodů byla skutečnost, že minerály $\mathrm{Sn}$ jsou z jiných lokalit s polymetalickým zrudněním na Havlíčkobrodsku nebo i z jiných lokalit stejného typu mineralizace známy (kasiterit, stanin). Druhým důvodem byl fakt, že v některých hornických areálech na Havlíčkobrodsku jsou v olověných slitcích občas zjištovány různé obsahy cínu. $Z$ analýz rudniny v Koječíně je však zřejmé, že těžené rudy nemohly být ani príležitostným zdrojem cínu.

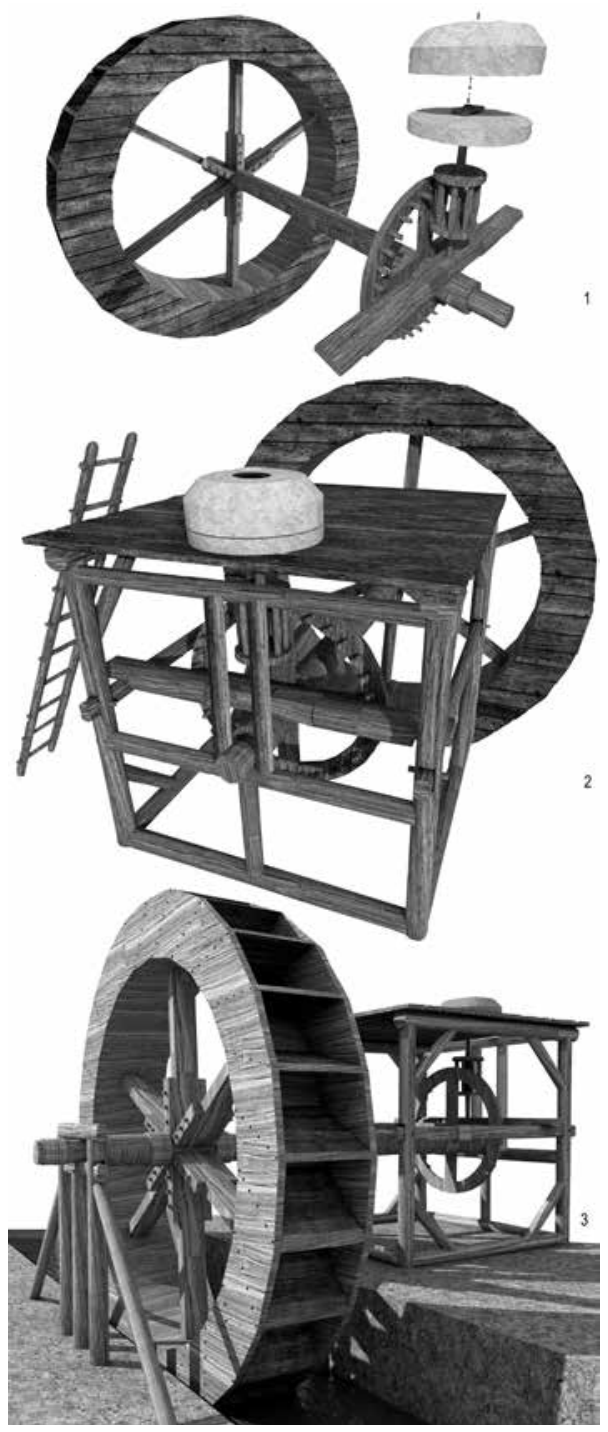

Obr. 32. Ideální trojrozměrný model rudního mlýna ze 13. až 14. století, v tomto př́ípadě poháněný spodní vodou. Vymodeloval M. Vágner.

Abb. 32. Ideales dreidimensionales Modell einer Erzmühle aus dem 13. bis 14. Jahrhundert, in diesem Fall angetrieben von einem unterschlächtigen Wasserrad. Modelliert von M. Vágner. 


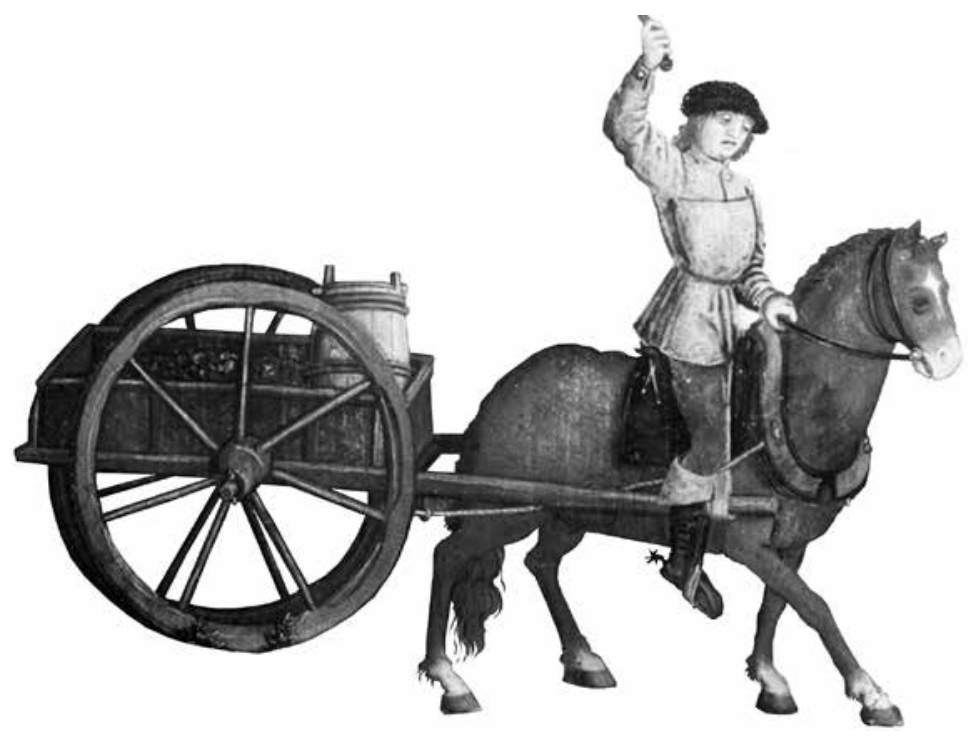

Obr. 33. Tažný kủň pracující na dolech, Annaberský oltář v kostele sv. Anny v saském krušnohorském městě Annaberg. Abb. 33. An Gruben arbeitendes Zugpferd, Annaberger Bergaltar in der St. Annenkirche der Stadt Annaberg im sächsischen Erzgebirge.

\subsection{Otázka hutnického pracoviště, hornického sídlišstě a majetkových souvislostí}

Z dokladů finálních fází technologického řetězce produkce kovů se i přes opakovanou prospekci zatím nepodařilo detekovat struskoviště, které bývá v těchto areálech typickým prvkem (též Rous-Malý 2004, 123, obr. 1: č. 12, 131). Stopy př́ítomnosti huti v podobě zlomků strusek nebyly zjištěny ani šlichováním technogenních sedimentů potoka. Jedinou indicií je tak výlitek olova, který však může souviset i s maloobjemovými metalurgickými operacemi, např́iklad s prubířstvím.

Další otázkou, třebaže v této fázi studia spíše podružnou, je prostorová detekce hornického sídliště. Indicie přináší zatím jen detektorová prospekce. Na základě distribuce kovových artefaktů lze vyslovit tezi, že sídliště se mohlo nacházet na východním břehu Nohavického potoka. Jedná se o mírný svah východně od potoka a jižně od pásma důlních jam. Kovové nálezy včetně stavebního kování se zde koncentrují na ploše okolo 1,5 ha (obr. 23). Příklady soudobých hornických osad v regionu nás přitom opravňují $\mathrm{k}$ hledání sídliště podél důlních jam (Derner-Hrubý 2018, 209-211, 213-215). Z těchto míst však zatím detektorové prospekce přinášejí vesměs negativní výsledky.

Otázkou jsou nakonec také majetkové poměry v době vzniku zdejších důlních a úpravnických provozů v polovině 13. století. Oblast mohla být zeměpanským zbožím. Nejasné je z tohoto pohledu postavení německých rytířů, kteří v roce 1233 prodali část svých majetků v blízkém Humpolci želivským premonstrátům (CDB III/1, 48-49 č. 48). Lze jen spekulovat, zda součástí těchto majetků mohlo být i území v okolí Herálce a Koječína. Podobně nejistě tím pádem vyznívá i úvaha o želivské kanonii jakožto držiteli území. V úvahu připadají také křižovníci s červenou hvězdou, kterým se humpolecké zboží dostalo roku 1253 (CDB IV/1, 454 č. 266). Nakonec je možné i to, že oblast byla součástí tvořícího se lichtenburského panství. 


\section{Literatura}

BAILLY-MAÎTRE, M.-Chr.-MINVIELLE LAROUSSE, N., 2011a: Éléments de méthodologie pour l'étude de meules et moulins à minerai médiévaux, Évolution typologique et technique des meules du néolithique àl'an mille. In: Actes des IIIe Rencontres Archéologiques del'Archéosite gaulois, Aquitania Supplément 23 (Buchsenschutz, O.-Jaccottey, L.-Jodry, F.-Blanchard, J.-L., dir.), 461-471. Bordeaux.

- 2011b: Ore grinding in the Middle Ages: the example of Brandes-en-Oisans (Isère, France). In: Bread for the people: the archaeology of mills and milling (Williams, D. F.-Peacock, D., edd.), 1-14. Oxford.

BERNARD, J. H., 1991: Empirical types of ore mineralization in the Bohemian Massif. Praha.

CDB III/1: Codex diplomaticus et epistolarius regni Bohemiae. Tomus III/1 (1230-1238) (Friedrich, G., ed.). Pragae 1942.

CDB IV/1: Codex diplomaticus et epistolarius regni Bohemiae. Tomus IV/1 (1241-1253) (Šebánek, J.-Dušková, S., edd.). Pragae 1962.

CDB V/1: Codex diplomaticus et epistolarius regni Bohemiae. Tomus V/1 (1253-1266) (Šebánek, J.-Dušková, S., edd.). Pragae 1974.

CRKAL, J., 2018: Středověké hutnictví a hamernictví na Př́isečnicku. In: Derner, K. a kol., Středověké hornictví a hutnictví na Př́ísečnicku ve středním Krušnohoří - Mittelalterlicher Bergbau und Hüttenwesen in der Region Preßnitz im mittleren Erzgebirge. Archaeomontan 5. Veröffentlichungen des Landesamtes für Archäologie Sachsen. Band 68 (Smolnik, R., ed.), 139-188. Dresden.

DERNER, K.-HRUBÝ, P., 2018: Otázka zemědělství a potravinářské produkce zemědělských hornických komunit - Zur Frage der Landwirtschaft und Nahrungsmittelproduktion mittelalterlicher Bergbau kommunitäten, AH 43, 207-239.

GALUSOVÁ, L., 2015: Vodní mlýn jako objekt archeologického výzkumu - Watermills as Subject of archaeological Research, AH 40, 267-293.

HOLATA, L.-PLZÁK, J., 2013: Examinace procesu optimalizace „,archeologicky korektních“ způsobů vyhodnocení dat z leteckého laserového skenování zalesněné krajiny: Potenciál filtrace surových dat, problematika interpolačních algoritmů a způsobů vizualizace antropogenních tvarů v digitálních modelech reliéfu. In: Archeologie a letecké laserové skenování krajiny, 49-79. Plzeň.

HOLUB, M., 2018: Odhad množství stř́ibra obsaženého v polymetalických rudách ložiska Kutná Hora vytěžených od 13. století, Acta rerum naturalium 22, 17-52.

HRUBÝ, P.-HEJHAL, P.-MALÝ, K., 2007: Montanarchäologische Forschungen in Jihlava - Staré Hory (Iglau-Altenberg, Tschechien), Zeitschrift für Archäologie des Mittelalters 35, 17-60.

HRUBÝ, P. a kol., 2012: Hrubý, P.-Hejhal, P.-Hoch, A.-Kočár, P.-Malý, K.-Macháňová, L.-Petr, L.-Štelcl, J., Středověký úpravnický a hornický areál Cvilínek u Černova na Pelhřrimovsku, PA CIII, 339-418.

HRUBÝ, P. a kol., 2014: Hrubý, P.-Hejhal, P.-Kočár, P.-Libor, P.-Malý, K., Centrální Českomoravská vrchovina na prahu vrcholného středověku. Archeologie, geochemie a rozbory sedimentárních výplní niv. Spisy Filozofické fakulty Masarykovy univerzity 422. Brno.

CHÁB, J.-STRÁNÍK, Z.-ELIÁŠ, M., 2007: Geologická mapa České republiky 1: 500 000. Praha.

JEŽEK, B.-HUMMEL, J., 2001: Jiř́i Agricola: Dvanáct knih o hornictví a hutnictví. Praha.

KOČÁR, P.-KOČÁROVÁ, R., 2017: Koječín (okr. Havličkủv Brod). Předběžná zpráva o antrakologické analýze. Nepublikovaná zpráva.

KRAJÍC, R., 2003: Sezimovo Ústí - archeologie středověkého poddanského města. 3. Kovárna v Sezimově Ústí a analýza výrobků ze železa. Praha.

KUDRNÁČ, J., 1988: Písek (okr. Písek), Pod starou pazdernou. Nálezová zpráva. Archiv ARÚ AV ČR, Praha, v. v. i., čj. 4027/88.

KYNCL, T., 2018: Dendrochronologické datování dřevěných konstrukčních prvků nalezených při archeologickém výzkumu v údolí Nohavického potoka u Koječína. Výzkumná zpráva. DendroLab Brno. Nepublikovaná zpráva.

LEACHTENAUER, J. C.-DRIGGERS, R. G., 2001: Surveillance and Reconnaissance Imaging Systems: Modeling and Performance Prediction. Artech House.

LITOCHLEB, J., 1981: K těžbě zlata v okolí Humpolce, Rozpravy Národního technického muzea 76, Studie $\mathrm{z}$ dějin hornictví 11, 105-117.

LITOCHLEB, J.-MALEC, J.-SZTACHO, P., 1982: Př́íspěvek k mineralogii zlatonosného zrudnění z Orlíku u Humpolce, Sborník Jihočeského muzea - př́rodní vědy 22, 37-50.

LOSERTOVÁ, L. a kol., 2011: Losertová, L.-Buřival, Z.-Losos, Z.-Veleba, B., Pozůstatky po historické těžbě v okolí Humpolce, Acta rerum naturalium 10, 1-10.

MINVIELLE LAROUSSE, N., 2017: Les meules du moulin à minerai médiéval de Brandes-en-Oisans. In: Les meules du Néolithique àl'époque médiévale: technique, culture, diffusion. Actes du 2ème 
colloque du Groupe Meule, Reims, du 15 au 17 mai 2014. Revue Archéologique de l'Est. Supplément 43 (Buchsenschutz O.-Lepareux-Couturier S.-Fronteau G., edd.), 407-427. Dijon.

NÝVLTOVÁ FIŠÁKOVÁ, M., 2018: Analýza srsti a peří z Koječína (středověk). Nepublikovaná zpráva, ulož. v ARÚ AV ČR Brno, v. v. i.

PROCHÁZKA, R.-PEŠKA, M., 2007: Základní rysy vývoje brněnské keramiky ve 12.-13./14. století, PV 48, 143-299.

ROUS, P., 2004: Stříbrorudné hornictví na Havlíčkobrodsku od 13. do 17. století, Archaeologia technica 15, 49-58.

ROUS, P.-MALÝ, K., 2004: Průzkum terénních stop po zpracování polymetalických rud na Havlíčkobrodsku. In: Těžba a zpracování drahých kovů: sídelní a technologické aspekty. Mediaevalia archaeologica 6 (Nováček, K., ed.), 121-144. Praha - Brno - Plzeň.

SIBSON, R., 1981: A Brief Description of Natural Neighbor Interpolation. In: Inerpolating Multivariate Data (Barnett, V., ed.), 21-36. New York.

STRAßBURGER, M., 2014: Montanarchäologie und Wirtschaftsgeschichte des Bergbaus im Schauinsland vom 13. Jahrhundert bis um 1800. Teil I-III. Inaugural-Dissertation zur Erlangung des Doktorgrades der Philosophie an der Ludwig-Maximilians-Universität München. Nepublikovaný rukopis.

ŠTUHEC, S.-ZACHAR, J., 2017: Digital Photogrammetry. In: 3D digital recording of Archaeological, architectural and artistic heritage (Zachar, J.-Horňák, M.-Novaković, P., edd.), 33-53. Ljubljana.

VEČEǨA, J., 2004: Povrchové pozůstatky po těžbě rud a jejich vyhodnocení. In: Těžba a zpracování drahých kovů: sídelní a technologické aspekty. Mediaevalia archaeologica 6 (Nováček, K., ed.), 145-156. Praha - Brno - Plzeň.

VOSÁHLO, J., 1996: Metody vyhledávání a průzkumu stříbrorudných ložisek v rozmezí 13. až 18. století (se zrretelem k Jihlavskému rudnímu revíru). In: Stříbrná Jihlava 1996. Seminář k dějinám hornictví a důlních prací na Vysočině, 29-44. Jihlava.

ZAKŠEK, K.-OŠTIR, K.-KOKALJ, Ž., 2011: Sky-View Factor as a Relief Visualization Technique, Remote Sensing 3, 398-415. https://doi.org/10.3390/rs3020398

\section{Zusammenfassung}

Eine mittelalterliche Erzaufbereitungsanlage bei Koječín auf der Böhmisch-Mährischen Höhe: Erkenntnisse zur Silbergewinnung im Staat der letzten Přemysliden

Der vorliegende Beitrag stellt die Grabung im Aufbereitungsareal bei Koječín in der Region von Havlíčkův Brod vor (Abb. 1:7). Das Areal schließt an eine Grubenarbeitsstätte an (Abb. 2). Durch eine Grabung in Profil 1 wurden Schichten von aufbereiteten Roherzen freigelegt. Das Ganggestein war hauptsächtlich quarzhaltig. Die gängigsten Sulfide sind Sphalerit und Pyrit, weniger Galenit. Häufig ist Arsenopyrit (Abb. 14, Tab. 2). Mikroskopisch wurde Chalkopyrit festgestellt. Besonders im Galenit und weniger in Pyrit und Sphalerit befinden sich Inklusionen von Tetraedrit.

Unter diesem Horizont fanden sich Sedimente von gemahlenem Roherz. In der Basis gab es die niedrigsten Gehalte an schweren Elementen. Auf Ebene der Roherze und auch der technogenen Sedimente sind die Gehalte hingegen extrem (Abb. 13). Diese Sedimente überdeckten Konstruktionstannenhölzer, unter denen sich gefällte Bäume und Äste befanden (Abb. 9 und 10). Bei der Entnahme von Proben wurde eine Konzentration von Pferdehaaren entdeckt (Abb. 22). Die Fundsituation wurde ergänzt um Bruchstücke von zwei Mahlsteinen aus dem Flußbett (Abb. 16). Archäometallurgisches Material ist lediglich durch eine scheibenförmige Blei-Ofensau vertreten. Der Analyse nach handelt es sich um reines Blei (99,96 bis 98,83 Masse- \% Pb).

An ältesten Spuren menschlicher Tätigkeit sehen wir die Rodung des mittelalterlichen Waldes. Relikte einer Holzkonstruktion erlauben zusammen mit Fragmenten von Mahlsteinen die Überreste eines Pochwerks und einer Mühle in Betracht zu ziehen (Abb. 30-32). Die Pferdehaare rufen die Vorstellung vom Transport des Roherzes von den Abbaugruben durch Pferdefuhrwerke hervor (Abb. 33). Die Fundsituation macht den Eindruck eines schnell angelegten kurzfristigen Standortes, der bald von den eigenen Betriebsabfällen vollgeschüttet war. 
Das hauptsächlich geförderte Erz war Galenit. Wir wissen nicht, ob die Silbermineralien während der Blütezeit nur mikroskopisch oder auch in Aggregatform vorlagen. Zu einer feinen Fraktion gemahlene Roherze deuten jedoch eher auf das Bestreben hin, Galenit und die darin gebundenen Inklusionen von Silbermineralien gravitativ voneinander zu trennen. Die Deponie kann ein Lager für qualitativ hochstehendes Roherz sein, das weiterverarbeitet werden sollte, wozu es aus unbekannten Gründen dann nicht mehr gekommen ist. Es kann sich auch um aufbereitetes und unbrauchbares Roherz von minderer Qualität gehandelt haben, von dem der wertvollere Teil bereits aussortiert wurde. Der Metallgehalt in Prozenteinheiten bis zu Zehntel Masse- \% für $\mathrm{Pb}$ und den ersten Hundertsel ppm für Ag kann bei aussortierten Roherzen als Standard angesehen werden (Tab. 2).

Bislang wurde weder eine Schlackenhalde, noch eine Siedlung entdeckt. Eine weitere Frage sind die Eigentumsverhältnisse in der Mitte des 13. Jahrhunderts. Das Gebiet kann ein landesherrliches Gut gewesen sein, es konnte dem Kloster Seelau gehören, aber auch zur Herrschaft Lichtenburg gehört haben.

Die vorliegende Studie entstand bei der Umsetzung des Projektes Nachhaltige Entwicklung der Kulturlandschaft und Schutz historischer Denkmäler in Waldgebieten, Projektcode: TL02000111.

doc. Mgr. Petr Hrubý, Ph.D., Ústav archeologie a muzeologie Filozofické fakulty Masarykovy univerzity, Arna Nováka 1, 60200 Brno, Česká republika,PetrSilberbergbau@seznam.cz

Martin Košt’ál, Ústav archeologie a muzeologie Filozofické fakulty Masarykovy univerzity, Arna Nováka 1,60200 Brno, Česká republika,462845@mail.muni.cz

RNDr. Karel Malý, Ph.D., Muzeum Vysočiny Jihlava, Masarykovo náměstí 55, 58601 Jihlava, Česká republika,maly@muzeum.ji.cz

Mgr. Jakub Těsnohlídek, Archaia Brno, z. ú., Bezručova 78/15, 60200 Brno, Česká republika, archaiajihlava@volny.cz 
